\author{
Federal Reserve Bank of New York \\ Staff Reports
}

\title{
The Use of Collateral in Bilateral Repurchase and Securities Lending Agreements
}

\author{
Viktoria Baklanova \\ Cecilia Caglio \\ Marco Cipriani \\ Adam Copeland
}

Staff Report No. 758

January 2016

Revised October 2017

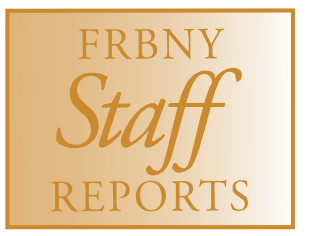

This paper presents preliminary findings and is being distributed to economists and other interested readers solely to stimulate discussion and elicit comments. The views expressed in this paper are those of the authors and do not necessarily reflect the position of the Federal Reserve Bank of New York or the Federal Reserve System. Any errors or omissions are the responsibility of the authors. 
The Use of Collateral in Bilateral Repurchase and Securities Lending Agreements

Viktoria Baklanova, Cecilia Caglio, Marco Cipriani, and Adam Copeland

Federal Reserve Bank of New York Staff Reports, no. 758

January 2016; revised October 2017

JEL classification: E44, G12, G24

\begin{abstract}
We use unique data from U.S. bank holding company-affiliated securities dealers to study the use of collateral in bilateral repurchase and securities lending agreements. Market participants' use of collateral differs substantially across asset classes: for U.S. Treasury securities transactions, we find that haircuts are large enough to provide full protection from default, whereas the same is not usually true for equities transactions. Further, although most of the equities in our sample are each associated with a unique haircut, most of the U.S. Treasury securities are each associated with more than one haircut. We relate these findings to implications of the zero value-at-risk feature that can be found in theories of collateral as an enforcement mechanism, and show that the data do not confirm these implications. We then turn to models of adverse selection that predict a negative relationship between haircuts and interest rates, based on the use of collateral as a screening mechanism. We find this negative relationship only for those trades in which the securities dealers are receiving U.S. Treasury securities and delivering cash.
\end{abstract}

Key words: repo, securities lending, adverse selection, haircut

Cipriani, Copeland: Federal Reserve Bank of New York (emails: marco.cipriani@ny.frb.gov, adam.copeland@ny.frb.gov). Baklanova: Office of Financial Research (email:

viktoria.baklanova@ofr.treasury.gov).Caglio: Federal Reserve Board of Governors (email: cecilia.r.caglio@frb.gov). This paper was previously distributed under the title "A New Survey of the U.S. Bilateral Repo Market: A Snapshot of Broker-Dealer Activity." The authors wish to thank Ana Fostel, as well as seminar and conference participants, for their comments and suggestions. The authors thank Jacob Adenbaum, Ocean Dalton, and Noah Zinsmeister for their excellent research assistance. The views expressed in this paper are those of the authors and do not necessarily represent the position of the Office of Financial Research, the U.S. Treasury, the Federal Reserve Bank of New York, the Board of Governors of the Federal Reserve, or the Federal Reserve System. 


\section{Introduction}

Securities dealers use securities financing transactions - repurchase agreements (repos) and securities lending contracts - to borrow funds on a collateralized basis, to provide funding to others, and to borrow or lend specific securities, often using cash as collateral. These transactions are vital to the functioning and efficiency of financial markets. Motivated by the recent financial crisis, regulators have begun to collect detailed data on securities financing transactions to obtain a deeper, detailed understanding of these trades. ${ }^{2}$ To date, these collections are not comprehensive, but rather focused on only some of the segments of the overall market (Baklanova, Copeland, and McCaughrin (2015)). Consequently, although there is a growing literature on the U.S. tri-party repo and parts of the securities lending market, little is known about the bilateral securities financing market, a large segment of the overall securities financing activity. ${ }^{3}$ In this paper, we fill the gap in the literature by using a unique data set to study the bilateral securities financing segment, with a focus on the role of collateral.

Our data are cross-sectional: three snapshots taken in the first quarter of 2015 of all non-matured securities financing contracts entered into by the U.S. broker-dealer entities of nine bank holding companies that are considered large players in this market. We estimate that our sample covers roughly one-half of all bilateral securities financing activity and so provides a comprehensive perspective of the market. Indeed, as far as we know, these data are the first to provide a representative view of bilateral securities financing activity, complementing the existing work on the tri-party repo market (see, for example, Copeland, Martin, and Walker (2014b) and Krishnamurthy, Nagel, and Orlov (2014)).

We leverage these data to first provide stylized facts about the bilateral securities financing market. This is quite a large market; our data cover $\$ 1.6$ trillion of securities on loan and \$1

\footnotetext{
${ }^{2}$ Adrian et al (2013) makes the case that transaction-level data should be collected on repo and securities lending activity, so as to promote a deeper understanding of these markets, to better monitor them, and to guide policy.

${ }^{3}$ The U.S. repo market can be separated into two segments based on differences in settlement: tri-party and bilateral. In tri-party repos, a clearing bank provides clearing and settlement services. In bilateral repos, the cash provider is responsible for the valuation and margining of the collateral pledged by the borrower. The U.S. tri-party repo market is considered more transparent as the clearing banks provide daily activity reports to the authorities. Aggregated data are publicly available, see https://www.newyorkfed.org/data-and-statistics/data-visualization/tri-partyrepo/index.html.
} 
trillion securities borrowed, by market value. ${ }^{4}$ Transactions backed by U.S. Treasuries dominate in terms of value (81 percent of securities on loan and 61 percent of securities borrowed), followed by equities, private-label structured products (collateralized mortgage obligations, mortgage-backed securities (MBS), and asset-backed securities) and corporate debt. Evidently, bilateral securities financing transactions mostly involve the trading of 'safe' securities with little market risk.

The maturity of trades is short. The share of bilateral transactions involving equities and corporate debt which are open (i.e. able to be terminated at any time by either party to the trade) is 90 and 76 percent, respectively. The maturity distribution of transactions involving U.S. Treasuries is less concentrated; nevertheless, 44 percent of them are open or have an overnight maturity.

In terms of counterparty, more than half of the trades in terms of dollar volume involve a bank or a broker-dealer, followed by hedge funds. This result differs widely from that of tri-party repo, where the money market funds and the cash reinvestment arms of securities lending agents are the largest participants.

We observe a range of rates both within an asset class as well as for a specific security type. This distribution reflects different motivations across trades, where typically positive rates are associated with funding trades and negative rates with specials. ${ }^{5}$ For most of the asset classes, the mean rate is positive. The exceptions are transactions backed by equities and corporate debt, where the negative average rate indicates that most trades are motivated by parties seeking to borrow securities that are in scare supply. Given their dominant place in this market, we focus on trades involving U.S. Treasuries, and observe there is wide variation in rates across securities as well as for a given security. This evidence likely reflects the heterogeneity of participants, and of their motives.

\footnotetext{
${ }^{4}$ In this paper, securities on loan and securities borrowed are considered from the standpoint of a reporting dealer. ${ }^{5}$ Specials are the securities which are in scarce supply. When the demand for a specific security is greater than the available supply, the interest rates associated with the cash leg of a bilateral securities transaction are usually negative. This implies that the party borrowing the securities is earning a negative return on its cash. There is a literature that focuses on understanding securities that go on special, including works such as Duffie (1996), Jordan and Jordan (1997), Buraschi and Menini (2002), and Fleming and Garbade (2007), as well as more recent work by, for example, D’Amico, Fan, and Kitsul (2013).
} 
Finally, we also document the distribution of haircuts within an asset class. Although there are a range of haircuts observed for each asset class, each distribution incorporates substantial mass points. We find the majority of U.S. Treasury trades have a zero haircut, reflecting the dealers' use of the Fixed Income Clearing Corporation's bilateral repo netting service. For equities (and to a less extent, corporate debt), the majority have haircuts of -2, reflecting the fact that securities dealers source equities from securities lending agents, which typically demand to be overcollateralized by 2 percent. $^{6}$

With these stylized facts in mind, we turn to understanding the role of collateral in this market. We start by considering the theory that collateral's sole role is as an enforcement mechanism for repayment. A common feature in this literature is that the amount of collateral posted is such (either by assumption or derived endogenously) that its value in the worst state of the world is equal to the amount of cash loaned out. The firm lending money, then, is never at risk of losing its principal. This zero value-at-risk feature holds, for example, in Geanakoplos (2003, 2010), Gromb and Vayanos (2002), Brunnermeier and Pederson (2009), Garleanu and Pederson (2011), Martin, Skeie, and von Thadden (2014) and Fostel and Geanakoplos (2015). ${ }^{7}$ An implication of zero value-at-risk is that the characteristics of the asset posted as collateral will alone determine the size of the haircut.

We test the zero value-at-risk feature in two ways for those trades involving U.S. Treasuries, equities, and corporate debt securities, which are the three most actively traded asset classes in our data. First, we examine whether each unique type of security, hereafter CUSIP (a unique identifier of a security), is associated with only one haircut, an implication that would hold if asset characteristics alone determine the haircut. ${ }^{8}$ Second, the role of collateral as an enforcement mechanism implies that haircuts are determined by the tails of the price distribution of the

\footnotetext{
${ }^{6}$ For recent information on the haircuts charged by securities lenders, see Baklanova et al. (2016a), which analyzes trade-level data collected from seven securities lending agents.

${ }^{7}$ The baseline model in Geanakoplos $(2003,2010)$ features no default in equilibrium because loans are endogenously collateralized according to the worst scenario. For example, Fostel and Geanakoplos (2015) deliver a zero-value at risk result in a general equilibrium model of a binomial economy with endogenous leverage, financial assets, and costly collateral. Note that although zero value-at-risk is a common feature of general equilibrium models of collateral, it does not generally follow from the role of collateral as an enforcement mechanism, unless there are frictions on collateral and default. Furthermore, default can be generated in general equilibrium models of collateral; for example, if the asset posted as collateral has two or more continuation states (see for instance Gong and Phelan, 2017; and Gong and Phelan, 2017b). Technically, Brunnermeier and Pederson (2009) have a $\pi$ value-atrisk assumption, where $\pi$ is assumed to be a non-negative number close to zero.

${ }^{8}$ In the data, securities are identified by CUSIP or ISIN.
} 
securities exchanged. We test this implication by comparing the level of negotiated haircuts to the price distributions of the securities exchanged.

Overall we get mixed results. For transactions involving U.S. Treasuries, we find that a majority of individual CUSIPs are not associated with a unique haircut, but with two or more. Moreover, we find little evidence that haircuts are correlated with the price distribution of the securities exchanged, as predicted by the theory. However, the level of haircuts set is typically large enough to protect against default.

For equities trades, we find that 96 percent of CUSIPs are associated with a single haircut. However, there is only weak evidence that haircuts are correlated with the securities’ price distribution and the level of haircuts often implies that over-collateralization is too low to enforce repayment when there are large (but plausible) changes in equities’ prices.

Finally, for transactions involving corporate debt securities, in line with the zero-value at risk theory of collateral, we find that roughly 85 percent of CUSIPs are associated with a single haircut and roughly 75 percent of haircuts are large enough to protect against the cost of default. However, the expected correlation between haircuts and the price distribution is absent for the vast majority of CUSIPs.

Overall this evidence shows that the implication of zero value-at-risk is not fully confirmed by the data. This may be due to the fact that some of the assumptions are too restrictive or that collateral may have a different role than that of a simple enforcement mechanism, especially for bilateral repo transactions involving US Treasuries and equities.

Another common prediction in the theoretical literature is that collateral can be used to reduce adverse selection because safer firms are willing to post more collateral to signal their quality and so get lower rates (Bester, (1985), Chan and Kanatas (1985), Chan, Greenbaum, and Thakor (1986) and Besanko and Thakor (1987a and 1987b)). ${ }^{9}$ A prediction of these adverse selection

\footnotetext{
${ }^{9}$ Bester (1985), for example, considers the classic case of banks providing secured lending to two types of firms, where firms differ in their ability to repay their loans (high ability for a "safe" firm and low ability for a "risky" firm) and banks do not observe these differences. He shows that banks can profitably lend to both types of firms by setting up a screening mechanism. Specifically, in equilibrium, banks will offer two types of loan contracts: a high interest rate and low haircut contract and a low interest rate and high haircut contract. This menu of contracts results in an equilibrium characterized by a separation of borrowers with different risk profiles. The safe firms choose a low rate/high haircut contract, and the risky firms choose a high rate/low haircut contract.
} 
models is that there should be a negative correlation between haircuts and rates. In particular, these theories can explain the use of multiple haircuts for a CUSIP, a feature that we frequently observe for transactions that involve U.S. Treasuries (but not for equities and corporate debt). This negative relationship between rates and haircuts is well documented in the previous empirical literature (e.g., see the recent work by Auh and Landoni (2016) and Cerqueiro, Ongena, and Roszbach (2016)). ${ }^{10}$

We apply this prediction to our data for U.S. Treasuries transactions. Specifically, we use a fixed-effect least squares approach to estimate how changes in haircuts affect rates. To address the endogeneity concern between rates and haircuts, whereby an unobserved characteristic of the tuple (dealer, counterparty, CUSIP) drives both the selection of the haircut and the rate, we use instrumental variables for the haircut negotiated between a dealer-counterparty pair.

The construction of our instruments is based on a timing assumption that dealers and their counterparties agree to haircuts in an initial stage, and then later negotiate rates. ${ }^{11}$ As explained in more detail later in the paper, this timing assumptions allow us to instrument for the haircut negotiated between a dealer-counterparty pair as a function of the characteristics of other market participants that enter into transactions involving the same CUSIP. ${ }^{12}$

We find a negative relationship between haircuts and rates only for those transactions in which dealers provide cash and receive U.S. Treasuries. Our estimate implies that if the haircut increases by one standard deviation ( 0.67 percentage point), then the rate impact is negative 7.8 basis points, a large effect given the median rate is 11 basis points. This result indicates that the haircut-rate tradeoff is substantial and suggests that a major source of the rate variation we observe for a given CUSIP within the day may be the result of firms’ using collateral as a screening mechanism.

\footnotetext{
${ }^{10}$ This evidence is also consistent with other theories. For example, as mentioned in later in this paper, Kuong (2016) generates this theoretical prediction using a model of moral hazard. A negative relationship between haircut and collateral is also derived in collateral GE models when more than one debt contract is traded in equilibrium (see e.g. Fostel and Geanakoplos, 2015).

${ }^{11}$ Later in the paper, we argue in more detail that this timing convention reflects how the securities financing market works in practice.

${ }^{12}$ This approach to constructing instruments is based on work in the industrial organization literature, which uses functions of the characteristics of competing products to instrument a particular product's price. For example, see Bresnahan (1981), Berry, Levinsohn, and Pakes (1995), and Nevo (2000).
} 
We do not find a negative relationship for those trades in which dealers deliver U.S. Treasuries and receive cash. Therefore, for that part of the bilateral securities financing market our work suggests that adverse selection is not an important factor or is addressed through other mechanisms.

We do not implement our test on the data for equities and corporates because in the data there is hardly any variation in haircuts for a given CUSIP. This lack of variation in haircuts for equities and corporates (and hence lack of a negative relationship between rates and haircuts) suggests that market participants do not seem to use haircuts as a screening mechanism to mitigate adverse selection.

This paper contributes to several strands of the financial economics literature. Our analysis contributes to a small but growing literature focused on understanding the vital but still relatively unknown securities financing market. Gorton and Metrick (2012) illustrate the importance of repurchase agreements in the 2007-09 financial crisis; Copeland, Martin, and Walker (2014b), and Krishnamurthy, Nagel, and Orlov (2014) analyze activity in tri-party repo, an important funding market for larger broker-dealers, over the crisis. In addition, Hu, Pan, and Wang (2015) study the determinants of tri-party repo pricing. Our focus on bilateral repos and securities lending is novel and our data are unique. Auh and Landoni (2016) also study bilateral repo trading; however, their paper is a case study of a hedge fund that uses repo trades to borrow cash and finance private-label mortgage-backed securities. This type of collateral accounts for only a small share of the overall bilateral repo market, as our dataset showed. Our work is focused on understanding the market more broadly and how collateral is used in trades involving securities from the most commonly used asset classes and across many different types of participants. As in Auh and Landoni (2016), we explore whether there is a negative relationship between rates and haircuts. They find such a relationship in their data; we do as well, but only for the subset of trades where dealers deliver U.S. Treasuries.

The results of testing for the role of collateral as a screening mechanism build upon a large empirical literature that looks for evidence of asymmetric information in various financial markets. Recent papers that, like ours, focus on adverse selection include Godlewski and Weill (2011), Berger et al. (2011a), and Berger, Frame, and Ioannidou (2011b). The main difference between our work and the existing literature is our focus on the securities financing market. A 
further difference is our instrumental variables approach, which draws from the industrial organization literature.

Complementary to this paper is the empirical literature on the role of collateral in addressing issues of moral hazard (see, for example, Cerqueiro, Ongena, and Roszbach (2016)). A typical channel for moral hazard is actions by the firm borrowing cash that influence the value of the collateral posted by that firm (see, for example, Kiyotaki and Moore (1997)). Because this paper focuses on financial markets in which the prices of the securities exchanged are not likely to be affected by the actions of individual firms, this moral hazard channel is probably not present.

The remainder of the paper is structured as follows. Section 2 reviews the data, beginning with a brief description of how the data were collected, followed by a description of the data and the U.S. bilateral repo market. Section 3 considers whether implications of the zero value-at-risk feature common to theories of collateral are observed in the data. Section 4 focuses on transaction involving U.S. Treasuries and tests whether the data are consistent with collateral being used as a screening mechanism, to address adverse selection. Section 5 concludes.

\section{Data}

In this section, we first describe the pilot data collection effort undertaken by the U.S. Treasury's Office of Financial Research (OFR) and the Federal Reserve. We then describe the data collected by the pilot.

\section{A. The Pilot}

Before the 2007-09 financial crisis, regulators and policymakers in the United States had only limited access to data on repo and securities lending activity, which impeded their ability to identify emerging risks in these markets and make well-informed policy decisions. As part of a series of initiatives to fill this gap, in 2014 the OFR and the Federal Reserve launched a voluntary pilot data collection effort focused on the bilateral repo and securities lending market. ${ }^{13}$ Nine bank holding companies (BHCs) participated in the pilot on a voluntary basis, reporting trades executed by their U.S. BHC-affiliated securities dealers. Although the pilot initially focused on collecting data on bilateral repo trades, on advice from participating dealers,

\footnotetext{
${ }^{13}$ For a description of the pilot program, see Office of Financial Research, "Bilateral Repo Data Collection Pilot Project,” online content, available at https://financialresearch.gov/data/repo-data-project/.
} 
it was broadened to include economically equivalent trades documented under securities lending agreements. Indeed, the economic effect of a repo contract can also be accomplished using a securities lending contract in which a security is lent (for a fee) using cash as collateral. ${ }^{14}$

Through the pilot, snapshots of the dealers' books were collected at the close of three reporting days in 2015: January 12, February 10, and March $10 .{ }^{15}$ Transaction-level details were reported on all outstanding U.S.-dollar-denominated bilateral repo and securities lending contracts against cash at the end of these dates, including the cash principal amount, the interest rate on the cash, the maturity of the trade, the value and type of securities delivered, the haircut applied to those securities, and the counterparty to the transaction (Table A1 in the Appendix lists all the variables collected in the pilot). ${ }^{16}$

\section{B. Data Description}

In this section, we describe the data used in this study. We refer to all transactions in which the reporting dealer receives securities and delivers cash as securities-in transactions, regardless of whether the transaction is documented as a repurchase or securities lending agreement. Similarly, we refer to all transactions in which the reporting dealer delivers securities and receives cash as securities-out transactions.

[Insert Table 1 here]

Table 1 reports the aggregate principal amount for securities-in and securities-out for each of the three reporting days. Over the three days, securities dealers lent, on average, \$1.6 trillion and borrowed, on average, $\$ 1$ trillion. To understand the pilot's coverage of the entire market, we compare these totals to estimates of the total market using the method outlined in Copeland et al.

\footnotetext{
${ }^{14}$ The participating dealers reported that counterparties sometimes prefer to use a securities lending contract when negotiating an exchange of cash for collateral, perhaps reflecting differences in prevailing market practice or regulatory requirements. By collecting data on repos and securities lending trades against cash, the pilot aims to get a more complete picture of the bilateral repo market. Not all securities lending contracts replicate the payoff of a repo agreement; in particular, under a securities lending contract, a security can also be lent using an asset other than cash as collateral. This type of securities lending transaction is beyond the scope of the pilot.

${ }^{15}$ These three days coincide with the Federal Reserve Bank of New York’s publication of tri-party repo statistics. See Tri-Party Repo Infrastructure Reform website for aggregate statistics on tri-party repo and GCF Repo activity. ${ }^{16}$ Specifically, we included transactions executed under an MRA (master repurchase agreement) or a GMRA (global master repurchase agreement), as well as those trades executed under an SLMA (securities lending master agreement) or a GSLMA (global securities lending master agreement) when securities were exchanged for cash. The template and instructions used in the pilot can be found at the Office of Financial Research's Bilateral Repo Data Collection Pilot Project website.
} 
(2014a). ${ }^{17}$ For both securities-in and securities-out, we find that the total value of bilateral repo and securities lending against cash captured in the pilot amounts to about half of the estimated size of the market for bilateral repo and securities lending against cash. ${ }^{18}$

For the remaining statistics and analysis presented in the paper, we exclude inter-company trades by affiliated parties in which the securities dealer's counterparty to the trade is part of the same BHC. We remove these inter-company trades because it is unclear whether they are done at arm's length. These inter-company trades account for 31 percent of our data on a dollar-value basis. By removing the inter-company trades, the average total value of securities-in and securities-out drops to $\$ 1.233$ trillion and to $\$ 567$ billion, respectively.

[Insert Table 2 here]

Next, we examine the use of repurchase agreements versus securities lending contracts. Overall, we find that whereas a larger number of transactions are executed through securities lending contracts, repos account for the majority of value exchanged in the bilateral market. Table 2 reports the use of securities lending contracts by asset class. We find that when dealers receive or deliver equities, securities lending contracts are almost exclusively used; dealers also heavily rely on securities lending contracts when dealing with corporate debt securities. For U.S. Treasuries and agency securities, in contrast, dealers mostly use repo contracts.

Table 3 reports total activity by asset class. Transactions backed by U.S. Treasuries dominate in terms of value, especially for securities-out transactions, where they represent 81 percent of total activity. The second largest collateral asset class is equities, which represent 21 percent of securities-in and 15 percent of securities-out by value. In terms of number of trades, however, transactions backed by equities dominate, reflecting the much smaller principal amount of the average bilateral equities transaction. Other important collateral asset classes are private-label structured products (collateralized mortgage obligations, mortgage-backed securities (MBS), and asset-backed securities) and corporate debt. The negligible amount of government agency MBS

\footnotetext{
${ }^{17}$ In Copeland et al. (2014a), the size of the overall repo market is estimated using regulatory filings (Form FR2004). The size of the bilateral repo market is then estimated as a residual after subtracting the tri-party repo and GCF Repo segments.

${ }^{18}$ The estimates of the size of the bilateral securities financing market are provided in Table A2 in the Appendix.
} 
activity is striking, as it contrasts with what is found in tri-party repo, where government agency MBS accounted for more than one-fourth of the total activity in $2015 .^{19}$

\section{[Insert Tables 3 and 4 here]}

Table 4 reports information on trade maturities by asset class. Most trades have quite short maturities. We find that 44 percent of trades collateralized by U.S. Treasuries are overnight or open trades (trades that can be terminated at any time by either party) and only 20.5 percent of the trades have a maturity greater than one day and up to a month. Finally, 35 percent of transactions involving U.S. Treasuries have a maturity longer than one month. Bilateral trades involving equity securities have even shorter maturities, with 90 percent being open. Bilateral trades involving corporate debt are also mostly of short maturities, with 76 percent being open trades.

\section{[Insert Figure 1 here]}

Figure 1 shows the share of activity by the type of counterparty to the trade. ${ }^{20}$ More than half of the activity is done with counterparties classified as "Banks" or "Broker-Dealers," for both securities-in and securities-out transactions. Banks are the largest counterparty type for securities-in, whereas broker-dealers are the largest for securities-out. The third and fourth largest types are "Hedge Funds" and "Other.” This makeup of counterparties to securities dealers differs widely from that of tri-party repo, where more than half of the dollar volume is traded with money market mutual funds and the cash reinvestment arms of securities lending agents (Alkan et al. (2013)).

\section{[Insert Table 5 here]}

Table 5 shows interest rates by asset classes, for overnight and open trades. (We exclude term trades to make the rate comparison more meaningful.) Negative rates indicate that the firm receiving securities is making an interest payment to the security lender. This is usually done when the securities borrower wants to obtain special securities. Positive rates indicate that the firm borrowing cash made an interest payment. For most asset classes, the average interest rates

\footnotetext{
${ }^{19}$ The Federal Reserve Bank of New York publishes monthly data on tri-party repo activity on its interactive website.

${ }^{20}$ We use the counterparty classification provided by the reporting dealers.
} 
are positive, and so the firm borrowing cash made the interest payments (see the columns labelled "Both In and Out" in Table 5). The exceptions are equities and corporate debt, in which the average interest rates are negative, indicating that the borrowed securities in these asset classes are in scarce supply. Note that although average rates are negative, the median rates for equities and corporates are still positive; that is, the distribution is skewed to the left: very negative interest rates on some hard-to-borrow securities drive the mean rate below zero.

Given the central role that U.S. Treasuries play in this market, we look more closely at the distribution of interest rates across different types of U.S. Treasuries. To provide for an appropriate comparison, we consider only overnight or open trades settled on the same reporting day, February 10, 2015. We then compute, for each CUSIP, the median interest rate as well as the $25^{\text {th }}$ and $75^{\text {th }}$ percentiles. As illustrated in Figure 2, the rates vary, both for a given CUSIP and across CUSIPs.

\section{[Insert Figure 2]}

The variation in the median rate across CUSIPs is quite large, ranging from less than -0.2 percent to more than 0.15 percent. This variation reflects, in part, differences in the economic drivers behind a trade. For bilateral trades used to raise funding, the level of interest rates on the transaction reflects the general value of cash in the U.S. money markets. For those trades executed to source collateral, the interest rate reflects the scarcity of the securities borrowed. The scarcer the supply of a CUSIP, the lower is the negotiated interest rate, with rates even going negative. As a point of reference, on February 10, 2015, the general collateral U.S. Treasuries interest rate was 5.4 basis points. ${ }^{21}$ The rate distribution in Figure 2 illustrates that there is substantial variation in funding rates and, in particular, that there are financial entities paying a large premium over the general collateral rate for their funding needs.

More striking is the variation in rates within a CUSIP. The mean difference between the $75^{\text {th }}$ and $25^{\text {th }}$ percentiles illustrated in Figure 2 is 7.7 basis points. This is particularly large given that the mean and median rate for bilateral U.S. Treasury trades is 2 and 9 basis points, respectively (see the last 2 columns of Table 5). The large interquartile spread demonstrates that even for trades

\footnotetext{
${ }^{21}$ The appropriate general collateral reference rate for bilateral repo trades is the average rate in tri-party repo. The Bank of New York Mellon publishes several general collateral reference rates, of which we use the U.S. Treasury index.
} 
involving the same U.S. Treasury security, different pairs of market participants are agreeing to vastly different interest rates, to the point where some participants earn rates close to the general collateral rate in the marketplace, whereas others earn negative rates. The large variation in rates across CUSIPs as well as for a single CUSIP also exists for equities and corporate debt, as illustrated in Figures A1 and A2 in the Appendix.

We then consider how interest rates vary by maturity for transactions involving U.S. Treasuries. For this analysis, we consider the spread between the negotiated interest rate and the USD LIBOR rate of equivalent maturity, and only consider transactions with a maturity less than or equal to one year. ${ }^{22}$ For each maturity, we computed the $25^{\text {th }}, 50^{\text {th }}$, and $75^{\text {th }}$ percentiles of the distribution of spread to USD LIBOR, and plotted them in figure 3. The majority of transactions with a maturity less than 1 month have a negative spread. For transactions with longer maturities, however, the median spread tends to be positive. The spread and the change in the spread are difficult to interpret however, because the rates in our data reflect differences both in counterparties and also economic purpose. Especially for transactions with short maturities, in our data we often see negative rates (and so negative spreads) because dealers are borrowing (or lending) securities which are in scarce supply. ${ }^{23}$

\section{[Insert Figure 3]}

\section{[Insert Table 6 and 7 here]}

Table 6 illustrates the distribution of haircuts by asset class. Haircuts are split into seven buckets (less than $-2,[-2,-1),[-1,0), 0,(0,1],[1,2)$ and greater than 2$)$, where "]" denotes that the endpoint is included in the bucket and ")" denotes that the endpoint is excluded. Haircuts are

\footnotetext{
${ }^{22}$ USD LIBOR provides an indication of the average unsecured rate at which large banks report being able to borrow for a given period. For cases where the securities financing transaction's maturity falls between the reported USD LIBOR rates, we use linear interpolation. Despite problems with the construction of LIBOR rates (see, for example, Snider and Youle (2014) and Bonaldi (2017)), USD LIBOR remains a popular reference rate in the U.S. money markets.

${ }^{23}$ Figure 3 also illustrates that secured rates are higher than unsecured rates for longer maturities, a curious phenomenon given secured rates are usually thought of having less counterparty risk. This "rate inversion" has also been observed elsewhere, for example when comparing U.S. Treasury general collateral rates to the fed funds effective rate (OFR Markets Monitor, April 2015). For our case, the rate inversion likely reflects differences between the participants setting USD LIBOR (large global banks) and those negotiating bilateral securities financing transactions with long maturities (a hodgepodge of financial entities).
} 
defined to be the difference between the value of securities exchanged and the cash principal, over the value of the securities. A positive haircut implies the party delivering cash against securities is over-collateralized, whereas a negative haircut implies the party delivering securities against cash is over-collateralized. ${ }^{24}$

The table numbers indicate the value-weighted share of haircuts by buckets and asset class. For example, 7.1 in the upper left corner of the table means that 7.1 percent of all U.S. Treasuries trades for which reporting dealers received securities (and delivered cash) had haircuts less than -2 percent. Moving along this top row, we see that 66.6 percent of these trades had a zero haircut. Indeed, a strong majority of U.S. Treasuries trades have zero haircuts for both securitiesin and -out, reflecting dealers’ heavy use of the Fixed Income Clearing Corporation's (FICC) bilateral repo netting service. ${ }^{25}$

In contrast to U.S. Treasuries, the majority of equities trades (whether the dealers are receiving the securities or delivering them) have haircuts in the -2 to -1 percent range (where we include -2 and exclude -1). These negative haircuts reflect the fact that securities dealers typically borrow equities from securities lenders, which demand to be over-collateralized. ${ }^{26}$

The same is true, although to a lesser extent, for corporate debt. Generally, the data collected through the pilot show that less liquid asset classes tend to attract more onerous haircuts, consistent with what is observed in tri-party repo (Copeland, Martin, and Walker 2014b). For example, municipal "securities-out” trades always transacted at haircuts below -2 percent, and for 96.3 percent of municipal “securities-in” trades, haircuts were above 2 percent.

A notable feature of haircuts is their heavy concentrations at one or two discrete values. In Table 7, we illustrate this finding by reporting the share of total activity traded at the mode, by asset

\footnotetext{
${ }^{24}$ In discussions with market participants, we learned that typically the more creditworthy firm charges the haircut.

${ }^{25}$ The FICC, a financial utility, offers a bilateral repo clearing and netting service to qualified firms (mainly brokerdealers). If both parties to a U.S. Treasuries bilateral repo trade (or other securities backed by the full faith and credit of the U.S. government) are FICC members, they can submit their trade details to the FICC. FICC both clears the trade and acts as a central counterparty by guaranteeing the settlement of the trade. Because of this guarantee, these trades have zero haircuts. The FICC protects itself from counterparty risk by having its members post securities as collateral into an FICC account, based on their overall historical FICC activity. In practice, parties often negotiate trades anonymously through interdealer brokers, and these brokers submit the trade details to the FICC. This anonymity is another benefit of the FICC’s bilateral repo service.

${ }^{26}$ Further evidence of this is found in Table 10 of Baklanova et al. (2016a), which analyzes trade-level data collected from seven securities lending agents.
} 
class. We see that 71.2 percent of U.S. Treasuries trades have zero haircuts. Further, 75.1 percent of equities trades have a haircut of -2 percent, and 44.6 percent of corporates also have a haircut of -2 percent. The concentration of trades at the mode falls for the other asset classes, although it is still around 20 to 30 percent for agency MBS, other agency, and municipality debt.

The concentration of haircuts at -2 percent for equities and corporates might reflect, in part, existing regulations or market practices. Many of the entities lending securities against cash are subject to regulations or rules that constrain the haircuts they are allowed to accept. ${ }^{27}$ For example, U.S. mutual funds are subject to specific requirements under SEC no-action letters regarding their securities lending practices, including requirements for collateralization. ${ }^{28} \mathrm{~A}$ U.S.-regulated fund must receive collateral equal to at least 100 percent of the value of the securities on loan; moreover, it is a generally followed market practice for funds to require 102 percent collateral for U.S. securities (a haircut of -2 percent) and 105 percent for international securities (a haircut of -5 percent). ${ }^{29}$ Similarly, the National Association of Insurance Commissioners found that insurance companies generally require borrowers to post cash collateral in the amount of at least 102 percent of the fair value of the loaned securities. ${ }^{30}$

With these stylized facts in hand, we now turn to our data analysis, which focuses on the role of collateral in this market.

\section{The Use of Collateral as an Enforcement Mechanisms}

In this section, we study whether the haircuts we observe are consistent with the zero value-atrisk feature that can be found in theories of collateral as an enforcement mechanism. In these models, which often focus on secured funding, it is assumed that without having posted collateral, firms will have no incentive to make their promised payments. ${ }^{31}$ Further, the amount

\footnotetext{
${ }^{27}$ See Lipson, Sabel, and Keane (2012) and Baklanova et al. (2016b) for detailed empirical work on these securities lending entities.

${ }^{28}$ For the SEC guidance on securities lending by U.S.-registered funds, see https://www.sec.gov/divisions/investment/securities-lending-open-closed-end-investment-companies.htm.

${ }^{29}$ See Investment Company Institute, 2014. "Securities Lending by Mutual Funds, ETFs, and Closed-End Funds: The Basics,” Viewpoints. Available at https://www.financialresearch.gov/working-papers/files/OFRwp-201517 Reference-Guide-to-U.S.-Repo-and-Securities-Lending-Markets.pdf.

${ }^{30}$ See National Association of Insurance Commissioners, 2011. "Securities Lending in the Insurance Industry," Capital Markets Special Report. Available at http://www.naic.org/capital_markets_archive/110708.htm.

${ }^{31}$ See, for example, Geanakoplos (2003, 2010), Gromb and Vayanos (2002), Brunnermeier and Pederson (2009), Garleanu and Pederson (2011), Martin, Skeie, and von Thadden (2014) and Fostel and Geanakoplos (2015).
} 
of collateral needed to secure a loan is typically set such that the value of the collateral in the worst state of the world is equal to the value of the loan. ${ }^{32}$ The bank or firm lending the money, then, is not at risk of losing the principal amount. An implication of this set-up is that the characteristics of the asset posted as collateral will determine the haircut on a loan.

We explore this general implication in our data using two approaches. First, we examine whether there is a one-to-one relationship between a CUSIP and a haircut. This is a strict test of the theory because it relies on market participants having the same beliefs about securities' price distributions. Second, we examine whether differences in securities’ expected payoff in low or high states of the world explain differences in their associated haircuts.

For the analysis in this section, we focus on transactions involving U.S. Treasuries, equities, and corporate debt. We also limit our sample to overnight and open transactions to sidestep the issue of how the tenor might impact the haircut; ${ }^{33}$ as shown in Table 4, overnight and open trades account for most of the trades in the data set. Furthermore, we drop bilateral repo trades with tiny principal amounts, because these trades were often executed for housekeeping reasons. ${ }^{34}$ Finally, we drop trades with zero haircuts for two reasons. First, for U.S. Treasuries, bilateral trades cleared through the FICC have zero haircuts, reflecting that FICC separately collects margins from its members on a portfolio basis. Second, for trades of all asset classes, a zero haircut sometimes reflects the fact that collateral is being held elsewhere and so is not captured in our data. As a result, a zero haircut in the data can be misleading. In Table A1 in the Appendix, we document how these filters affect the set of trades we examine. For equities and corporates, the tenor and zero haircut filters reduce the sample size by 17 and 31 percent, respectively. For U.S. Treasuries, the impact is much larger, with an 80 percent reduction, due to active use of the FICC’s bilateral repo service for clearing and settling inter-dealer trades. ${ }^{35}$

\footnotetext{
${ }^{32}$ The cash lender requires that the value of collateral in the worst state of the world be weakly greater than the principal amount. Because collateral is costly, the cash borrower posts collateral which is equal to the principal amount in the worst state of the world.

${ }^{33}$ Another reason to focus on overnight and open trades only is that they are close counterparties of the binomial economy studied by Fostel and Geanakoplos (2015).

${ }^{34}$ For U.S. Treasury and corporate trades, the minimum principal amount for a transaction to be included is $\$ 100$, whereas for equities trades it is $\$ 10$.

${ }^{35}$ We continue to exclude inter-company trades from our analysis, as was done in Section 2 (with the exception of Table 1).
} 
We consider trades with positive and negative haircuts separately. The difference in the sign of the haircut indicates which party in the transaction is over-collateralized: in a transaction with a positive haircut, the cash lender is over-collateralized, whereas in a transaction with a negative haircut, it is the securities lender. For bilateral securities financing transactions, both parties are concerned about default. Which party gets to be over-collateralized, or the result of whether a transaction has a negative or positive haircut, usually reflects which one of the counterparties has a higher default risk. ${ }^{36}$

Conditioning our analysis on the sign of the haircuts is important because, when charging haircuts, the two parties to the trade are worried about different price movements of the securities. Consider the case where a dealer is receiving securities and delivering cash. If the dealer is charging a haircut, it is protecting itself against a fall in the price of the security. But if the dealer is paying a haircut, then the dealer's counterparty is protecting itself against a rise in the price of the security. For a given CUSIP then, if the price distribution is not symmetric around zero, we should not expect the absolute value of the associated positive and negative haircuts to be equal. Because of this, we analyze trades with positive and negative haircuts separately.

Table 8 shows the distribution of the number of haircuts by CUSIP. We find that a one-to-one correspondence between a CUSIP and a haircut holds in the data to varying degrees. For the set of securities with positive or negative haircuts, we see that at least 90 percent of corporate debt securities are associated with one haircut. Similarly, 90 percent of equities securities (which only appear with negative haircuts) are associated with one haircut. In contrast, at least half of U.S. Treasuries with positive haircuts and more than 75 percent of those with negative haircuts are associated with multiple haircuts.

[Insert Table 8 and 9 here]

To assess its importance in terms of value traded, we compute the share of total value traded backed by CUSIPs associated with more than one haircut (see Table 9). For equities, we find that

\footnotetext{
${ }^{36}$ Up to and during the crisis, AIG used securities lending to source funds (Keane 2013). Until the crisis, AIG, as an insurance company, was considered more creditworthy than its securities dealer counterparties and so charged a haircut. Strikingly, during the crisis, AIG went from charging a haircut for funding to paying a haircut, as AIG's counterparties recognized its worsening creditworthiness (Peirce 2014).
} 
4 percent of the total value traded is backed by CUSIPs associated with more than one haircut. For corporates, 9 percent of the value of positive haircut trades are backed by CUSIPs associated with more than one haircut, and 15 percent for negative haircut trades. In contrast, for U.S. Treasuries, we find that more than 80 percent of the value traded, for either positive or negative haircut trades, is associated with more than one haircut; in other words, at least for U.S. Treasuries there is strong evidence that there are other factors, in addition to the characteristics of the individual CUSIP, that affect the haircuts in a securities financing transaction.

The share of value traded involving CUSIPs associated with more than one haircut differs according to whether the dealer is receiving or delivering securities. As shown in columns 4 and 5 of Table 9, securities-in transactions typically have a larger fraction of value with CUSIPs associated with more than one haircut compared to securities-out transactions.

Our second approach to testing the implication that only the asset's characteristics determine the haircut is to analyze whether the expected price jump (up or down) of the securities being traded explains the haircut on the bilateral repo trade. If the haircut is set so as to prevent default, we should observe that the haircut on an individual trade is driven by the tail of the price distribution of the securities exchanged.

We compute two measures of this expected value, which correspond to whether the party charging the haircut is concerned about the value of the securities falling or rising. To compute the first measure, we use price data for 2014 to compute daily price changes for each CUSIP given that the price change is negative. ${ }^{37}$ We then calculate the $10^{\text {th }}$ percentile of these negative price changes and label it the "expected price fall.” We then repeat the above method, but condition it on the daily price change being positive, and calculate the $90^{\text {th }}$ percentile of the resulting positive price changes. We label this second statistic the “expected price rise.” The first statistic captures cases in which the cash lender charges a positive haircut, and so is concerned about the potential fall in the value of the security tomorrow. The second statistic captures cases in which the securities lender charges a negative haircut, and so is concerned about having enough cash collateral on hand to repurchase the loaned security.

\footnotetext{
${ }^{37}$ We get price data for U.S Treasuries and equities from Bloomberg L.P. and prices for corporate debt from Trade Reporting and Compliance Engine (a.k.a. TRACE).
} 
We begin by exploring whether the haircut fully protects one of the counterparties in the case of fails or default by comparing the size of the haircut to the "expected price fall” (for positive haircuts) or the "expected price rise” (for negative haircuts) for each CUSIP. For positive haircuts, we label the pair (haircut, CUSIP) as "safe" if the haircut is larger than the absolute value of the expected price decline. Similarly, for negative haircuts, the "safe” label applies to pairs where the absolute value of the haircut is greater than the expected price increase.

We find that 80 percent of U.S. Treasury (haircut, CUSIP) pairs with positive haircuts are "safe," as are 91 percent of those with negative haircuts (see the first column of Table 10). Almost all of these pairs, then, have haircuts that are high enough to protect the party charging the haircut from being out-of-the money in case of a fail or default. ${ }^{38}$ For equities, we find a much smaller percent of "safe" pairs — only 22 percent have high enough haircuts to protect against an increase in the value of the security (recall that all equities have negative haircuts in our data). Finally, for corporate debt securities, we find that 79 percent of trades with positive haircuts and 72 percent of trades with negative haircuts are "safe."

[Insert Table 10 here]

We then measure the correlation of haircuts with the "expected price rise" or "expected price fall” of the associated securities. For trades with positive haircuts, the theoretical prediction is that the expected price fall should be negatively correlated with the haircut, because larger haircuts are needed to protect oneself against larger expected price falls. Similarly, for trades with a negative haircut, the prediction is that the expected price rise should be negatively correlated with the haircut.

For U.S. Treasuries, the correlation is -0.201 for trades with positive haircuts and -0.192 for those with negative haircuts, where both correlation estimates are highly statistically significant (see the second column of Table 10). We further explore this correlation in a regression context, because it allows us to control for institutional details, such as differences among dealers and their clients. We do this by regressing haircuts on the relevant expected price jump, controlling for the log of the principal and for dealers, counterparties, and time fixed effects. For trades with

\footnotetext{
${ }^{38}$ For outright defaults, our "safe" label is only appropriate if the party going into bankruptcy is small enough such that its counterparties can liquidate the securities held as collateral without affecting prices in the market or, alternatively, re-purchase their securities on-loan to the defaulting party without affecting prices.
} 
positive haircuts, the expected negative relationship holds with a statistically significant coefficient of $-23.5{ }^{39}$ For negative haircut trades, however, the estimated coefficient is not statistically significant.

For equities, the pairwise correlation is, as expected, negative and statistically significant. But the correlation is quite weak at -0.043 . In the regression, we also find the expected negative relationship; the estimated coefficient is -0.04 . Note that although statistically significant, the coefficient is economically tiny: a 10 percent "expected price rise" is associated with a 0.004 percentage point decrease in the haircut.

Finally, for corporates, the pairwise correlation is -0.125 and statistically significant for trades with positive haircuts but statistically insignificant for trades with negative haircuts. These results are confirmed by the regression, where we estimate a large in absolute value coefficient of -50.1 for “expected price falls” for trades with positive haircuts. For those negative haircut trades, the coefficient on expected price jumps is statistically insignificant.

Although it is encouraging that the predicted negative relationship holds between expected price jumps and haircuts for U.S. Treasuries and corporate debt trades with positive haircuts, it is a puzzle not to find this same negative relationship for those trades with negative haircuts. Rather, for negative haircut trades, this relationship is either economically tiny or statistically insignificant. For negative haircut trades, then, our results suggest that other factors, such as regulatory requirements, are likely as important, if not more, in determining haircuts. This is illustrated quite strikingly for equities with a scatter plot of haircuts and the "expected price rise" for each equity CUSIP in our data set (see Figure 4). For both haircut values of -2 and -5 percent, there is tremendous variation in the expected price jump, questioning the strength of the link between these two variables.

\section{[insert Figure 4 here]}

In summary, we find mixed evidence on the fact that haircuts are set to prevent default and are only a function of the characteristics of the collateral. Haircuts on U.S. Treasury bilateral trades are usually large enough to fully protect against fails or default, in line with the idea of collateral

\footnotetext{
${ }^{39}$ Standard errors are clustered by dealer and counterparty. Regression results are reported in Table A4 in the appendix.
} 
as an enforcement mechanism. However, a strong majority of U.S. Treasury CUSIPs are associated with multiple haircuts, a result at odds with the idea that haircuts are solely determined by the characteristics of the collateral (see Table 11 for a summary of results). Together then, these results suggest that other forces beyond mere enforcement are at play when determining haircuts for trades involving U.S. Treasuries in this market.

\section{[insert Table 11 here]}

Turning to equities, we find a strong majority of unique equities are associated with one haircut (either -2 or -5 percent). However, the expected price change of the equity security has only a weak correlation with the haircut. Further, only 22 percent of the CUSIP-haircut pairs in the data had haircuts large enough to fully protect the securities lender from default. Echoing the analysis of U.S. Treasury trades, these results suggest that other forces beyond enforcement are at play in determining haircuts. In addition, the differences in haircut setting between U.S. Treasuries and equity trades suggests that different economic forces may be in play across asset classes.

Finally, our results for corporate debt securities fall between those for U.S. Treasuries and equities. Roughly three-quarters of corporate debt CUSIPs are "safe," or have large enough haircuts to protect against default, and for those trades with positive haircuts, the correlation between haircuts and expected price decreases is both statistically and economically significant. Both of these results are in line with theories that posit that collateral's only role is enforcement. However, we find that for negative haircut trades, which make up the vast majority of corporate debt trades in our sample, the negative relationship between haircut and expected price increase is not significant, a finding not in line with these theories. Furthermore, a small but significant share of corporate debt CUSIPs are associated with multiple haircuts.

The above analysis considers the relationship between haircuts and the characteristics of the underlying securities at the transaction level. In contrast, one might think that securities dealers manage their haircuts at a portfolio level. In this case, analyzing collateral at an aggregated dealer-counterparty level would be more appropriate. However, in our data collection, securities dealers did not report that haircuts for securities financing trades typically reflected the current portfolio of trades between the dealer and the counterparty. Supporting these statements, we find that a given (dealer, counterparty, CUSIP) tuple is always associated with a single haircut. This 
holds even for those cases in which a tuple has trades with different start dates, when it is likely that across these start dates the portfolio of exposures between the two parties has changed.

The absence of default is another sharp prediction of the zero value-at-risk feature, but it is not a focus on this paper. Outright defaults on repo positions, although rare, do occur. Recent examples include the Lehman Brothers and MF Global bankruptcies, and Garbade (2006) provides additional examples of dealers defaulting on their repo contracts in recent history. In addition to outright defaults, technical defaults occur on a weekly, if not daily, basis. ${ }^{40}$ Some of these technical defaults are operational, relating to back-office mistakes with clearing and settlement. Others, however, are strategic. ${ }^{41}$ However, these strategic technical defaults may be outside of the typical enforcement theory of collateral, because they can be disguised as purely operational defaults. Unfortunately, we do not have data on defaults and fails for bilateral securities financing transactions with which to more fully explore the predictions of the theory in this market.

The results in this section highlight that although implications of zero value-at-risk match some features of the data, other important dimensions of the data are at odds with it, suggesting additional or alternative roles for collateral beyond mere enforcement. Building on this idea, in the next section we consider the alternative role for collateral as a screening mechanism in the presence of adverse selection, motivated especially by the result that some CUSIPs are associated with multiple haircuts.

\section{Asymmetric Information Model of Haircuts and Interest Rates}

As discussed in the introduction, there is a large literature explaining the use of collateral in debt contracts using models of asymmetric information. In this literature, in addition to providing

\footnotetext{
${ }^{40}$ As part of their Primary Dealer Statistics, the Federal Reserve Bank of New York reports the total value of fails by asset class. For U.S. Treasuries, excluding TIPS, the average weekly value of fails to receive by primary dealers is about $\$ 100$ billion over the first half of 2017.

${ }^{41}$ Until recently, settlement fails have largely been considered an operational error. However, some studies have suggested that episodes of elevated fails are related to a lack of incentives for market participants to avoid fails to deliver (see, for example, Fleming and Garbade (2005) and Evans, Geczy, Musto, and Reed (2009)).
} 
protection against default, collateral plays the role of a screening mechanism to mitigate problems caused by the presence of adverse selection. ${ }^{42}$

In the securities financing market, the economic motivations behind trades are more complex than those analyzed in most of the theoretical literature. Nevertheless, in this market the risk of default and the potential for adverse selection, which are highlighted in the literature, are relevant concerns.

Through the lens of these models of adverse selection the observation of multiple haircuts per CUSIP in our data, highlighted in Table 9, could be driven by adverse selection. A testable implication of this theory is that there should be a negative relationship between haircuts and rates.

\section{A. Identification}

To describe the relationship between the haircut and interest rate for a given CUSIP, we first introduce some notation. Let $t$ denote the reporting date and $j$ a specific trade in the data. The variable $\operatorname{sprd}_{j t}$ is the spread between the negotiated interest rate and the USD LIBOR rate of equivalent maturity. We use the spread rather than the negotiated rate, because the spread nets out macro interest rate variation. The variable haircut $_{j t}$ is the haircut, and $X_{j t}$ is a matrix of other trade-level characteristics as well as dealer and counterparty characteristics. For a given CUSIP, the spread equation we want to estimate is

$$
\operatorname{sprd}_{j t}=\alpha_{0}+\alpha_{1} \text { haircut }_{j t}+\alpha_{2} X_{j t}+\varepsilon_{j \mathrm{t}}
$$

where $\varepsilon$ is an iid error term.

Employing ordinary least squares will not yield a consistent estimate of $\alpha_{1}$, the coefficient of interest, because of endogeneity concerns. In particular, there are likely to be characteristics, unobserved by the econometrician, that affect both the interest rate spread and the haircut.

Our approach to solving this econometric problem is to construct instruments for the haircut variable. To motivate our instruments, we need to add more structure to the problem between the

\footnotetext{
${ }^{42}$ See, for example, (Bester, (1985), Chan and Kanatas (1985), Chan, Greenbaum, and Thakor (1986) and Besanko and Thakor (1987a and 1987b)).
} 
dealer and its counterparty by imposing a timing convention that the parties to the trade agree upon haircuts in an initial stage, and then rates are negotiated in a later stage.

Although the timing assumption is important for our econometric approach, it also aligns with our understanding of how this market works. Discussions with market participants suggest that traders negotiate interest rates on a much higher frequency compared to haircuts. Indeed, changing the haircut sometimes involves other groups within an institution, such as credit risk and legal departments, whereas interest rates are typically the prerogative of the trader. For similar types of trades that are documented as tri-party repo agreements (a related market in which dealers secure short-term funding from investors), this timing behavior is hard coded: haircuts are specified in the legal documents between two parties, whereas rates are left open to the traders negotiating the deals from day to day (Copeland, Martin, and Walker (2010)).

When negotiating the haircuts in the initial stage, the characteristics of both parties to the trade have an impact. Because these negotiations are happening among many parties in the market, in equilibrium the negotiated haircut between a specific dealer-firm pair will be a function of the characteristics of other dealers and firms that are present in the market. This implies that changes in the characteristics of other dealers and firms in the market should be correlated with changes to the negotiated haircut of a given dealer-firm pair. ${ }^{43}$ Further, these characteristics are independent of the error term in the interest rate equation (and therefore are valid instruments) because a specific dealer-counterparty’s unobserved characteristic is assumed to be independent of the characteristics of other dealers and firms. This last assumption seems reasonable, because it is difficult to imagine that the characteristics of firms that are active in this bilateral securities financing market depend on the unobserved characteristic of any specific dealer-firm pair. In practice, then, our instruments will be functions of the characteristics of firms in the market that are also entering into bilateral securities financing contracts involving the same CUSIP.

\section{B. Estimation}

For purposes of estimation, we focus on U.S. Treasuries because for this asset class we observe many instances in which unique securities are associated with multiple haircuts. As shown in our

\footnotetext{
${ }^{43}$ This approach to constructing instruments is often used in the industrial organization literature. For example, when trying to estimate price elasticities for differentiated products, researchers will instrument for a product's price using functions of competing products' characteristics. See, for example, Bresnahan (1981), Berry (1994), Berry, Levinsohn, and Pakes (1995), and Nevo (2000).
} 
earlier analysis in Section 3 (see Table 8 in particular), for securities financing transactions involving equities and corporates, there is hardly any haircut variation for a given CUSIP. As such, the predicted negative relationship between haircuts and rates for a given CUSIP that is found in models of adverse selection is not seen in the data. Because it is hard to believe that some asymmetric information is not present in these markets, we interpret our finding to simply mean that market participants do not use haircuts as a screening mechanism for securities financing trades involving equities and corporates, and likely address asymmetric information through other mechanisms, such as monitoring.

In taking Equation 1 to the data on securities financing transactions involving U.S. Treasuries, we jointly consider all CUSIPs and estimate the average local impact of a change in haircut on rates. For this analysis, we exclude trades with small principal amounts as well as those with zero haircuts, for the same reasons discussed in Section 3 above. Unlike the analysis in Section 3, we include term trades because the regression approach allows us to account for how tenor affects the spread in a flexible way. (See Table A1 in the Appendix for details on how these filters affect the set of trades we examine.) ${ }^{44}$

The regression we estimate controls for dealer, counterparty and CUSIP characteristics using fixed effects. There are $P$ dealer-counterparty pairs and $S$ CUSIPs. Let $p_{j t}$ denote the dealercounterparty pair associated with trade $j t$ and let $s_{i j}$ denote the CUSIP associated with that trade. The spread equation is then:

(2) $\operatorname{sprd}_{j t}=\alpha_{0}+\alpha_{1}$ haircut $_{j t}+\alpha_{2} X_{j t}+\sum_{k=1}^{P} \theta_{k}^{P} 1\left(p_{j t}=k\right)+\sum_{k=1}^{S} \theta_{k}^{S} 1\left(s_{j t}=k\right)+\varepsilon_{j t}$,

where $1(x=y)$ denotes an indicator function equal to 1 if $x$ is equal to $y$. Note that the summation terms are the dealer-counterparty pair and CUSIP dummy variables and their associated coefficients, respectively. The matrix $X$ includes the log of the cash principal amount, the tenor, and the square of the tenor of the trade. The dealer-counterparty pair fixed effects control for the characteristics of the dealer and counterparty, which affect the rate negotiated by this pair across

\footnotetext{
${ }^{44}$ For this analysis, we also check to see if a trade between a dealer-firm pair is recorded in the data as multiple transactions. Especially for larger trades, market participants might record a trade as a set of multiple transactions in which the only difference across the trades is the principal amount. This is done both to help parties better manage their intraday credit costs and to minimize the impact of an operational-related fail. We check for this in the data and aggregate up instances in which multiple trades are identical in counterparties, start date, rate, tenor, CUSIP, and haircut.
} 
all their transactions in the sample. The CUSIP fixed effect captures the average interest rate of transactions in which that unique security is exchanged. The variations in the data driving the estimate of $\alpha_{1}$ are changes in haircuts and spreads for a given CUSIP, where the change in the spread is not already explained by the associated trade characteristics in $X$ or by the fixed effects.

Our instruments are functions of the entity type of counterparties (see Figure 1 for a list of counterparty types). The first set of instruments we construct is based on competing counterparties' characteristics for trades of the same CUSIP completed with the same dealer. Specifically, for a trade $j$ t, we compute the fraction of all trades with the dealer entity of the pair $p_{j t}$ and CUSIP $s_{j t}$ done by each counterparty type, excluding those trades involving the counterparty entity of pair $p_{j t}$. The second set of instruments is based on counterparty characteristics for trades completed with other dealers. Specifically, for a given trade $j t$ we compute the fraction of all trades with dealers other than the dealer entity of pair $p_{j t}$ and CUSIP $s_{j t}$ done by each counterparty type.

For example, consider a trade between a dealer $\mathrm{D}_{1}$ and counterparty $\mathrm{C}_{1}$ for Apple stock. The instruments in our first set are constructed from the group of trades that also used Apple stock, involving $D_{1}$ and excluding $C_{1}$. From this group, we construct the share of trades by counterparty type, such as banks and broker-dealers. Instruments in our second set are constructed from the set of trades that used Apple stock, excluding both $\mathrm{D}_{1}$ and $\mathrm{C}_{1}$. From this set, we construct the share of trades by counterparty type.

Given the large sets of dummy variables involved, we use a two-stage least squares approach in which we first regress haircuts on the full set of instruments and generate predicted haircut values. We then use these predicted haircut values to estimate Equation 2 above. ${ }^{45}$

We consider separately trades in which the reporting dealer received U.S. Treasuries and those in which the reporting dealer delivered them because of observed differences across these two groups of transactions. In particular, the distribution of counterparty types differs across securities-in and -out (see Figure 1), as does the distribution of rates (see Table 5).

\footnotetext{
${ }^{45}$ We use the felsdvreg command in STATA, which handles two large sets of fixed effects in a computationally tractable way (Cornelissen 2008).
} 


\section{Results}

We start by considering securities-in trades. Our strategy is to first estimate the spread regression (Equation 2) with ordinary least squares and so ignore the endogeneity concern between haircuts and spreads. These OLS results provide a benchmark against which to compare our instrumental variables (IV) estimates. We then implement a two-stage IV estimation routine, for which we use our aforementioned instruments. As we detail below, we find a negative and significant relationship between haircuts and spreads, consistent with the use of collateral as a screening mechanism, only for the case where dealers receive U.S. Treasuries and deliver cash.

As shown in the top panel of Table 12, using OLS the estimated coefficient for haircuts is negative but statistically insignificant. ${ }^{46}$ The coefficient for the log of the principal amount is estimated to be negative and statistically significant, but the economic effect is small. We allow for a nonlinear relationship between spread and tenor by including both a tenor and a tenorsquared term in the regression. The tenor-squared coefficient is statistically significant, but both terms are economically insignificant.

We then estimate the spread equation using instrumental variables. ${ }^{47}$ The main result of our twostage instrumental variables approach is that the coefficient of haircuts in the rate regression becomes larger in absolute value and statistically significant, relative to the OLS case. This coefficient means that if the haircut moves from 0 to 1 percent, then the rate impact is 11.7 basis points.

To gain a sense of how much haircuts vary for a given CUSIP, we compute the standard deviation of haircuts by CUSIP conditional on there being more than one haircut value associated with a CUSIP. For transactions involving U.S. Treasuries securities-in, the mean of these standard deviations is 0.67 . A one-standard-deviation increase in a haircut generates a decrease of 7.8 basis points in the spread, an economically significant impact because the mean and median rates of U.S. Treasuries securities-in trades are 4 and 11 basis points, respectively (see the first two columns of Table 5). This result suggests that the use of collateral screening mechanisms has a first-order impact on rates and is likely a main driver in explaining interest rate variation for a given CUSIP (for example, see Figure 2).

\footnotetext{
${ }^{46}$ All standard errors are bootstrapped.

${ }^{47}$ Of the 24 instruments we constructed based on other participants' characteristics, we find that eight of them are statistically significant at the 90 percent confidence level, demonstrating the predictive power of haircuts.
} 
[Insert Table 12 here]

We then consider securities-out transactions. The OLS specification estimates a positive and statistically significant impact of a haircut on the spread. With our instruments, the effect of a haircut on the spread becomes statistically insignificant (see the results in the bottom panel of Table 12). In contrast to securities-in transactions then, we do not find evidence supporting the hypothesis that collateral is used as a screening mechanism for securities-out trades.

\section{Discussion}

Our empirical results are consistent with adverse selection being present for transactions involving securities-in U.S. Treasuries. Based on the institutional details of the securities financing market, we argue below that our results suggest that the adverse selection lies with the securities dealers and their probabilities of failing to return borrowed securities on the agreedupon date.

As discussed in the introduction, both parties to a bilateral securities financing trade are worried about default risk. Whereas outright defaults are rare, market participants regularly experience technical defaults or settlement failures, a milder form of default described at the end of Section 3. In particular, on the closing leg of the trade, the failure to return the borrowed securities on the agreed-upon date is a not-uncommon event.

Our results are consistent with adverse selection that arises from fails as opposed to outright default. The probability of failing to return a security will vary across both CUSIPs and firms, reflecting, for example, the supply of a particular CUSIP in the market or the gains to the firm borrowing the securities to using them in another deal. In contrast, the probability of an outright default, being at the firm level, is a more aggregate shock affecting all the trades into which a firm enters. Given that our empirical work controls for the dealer-counterparty pair, our results are consistent with adverse selection that is related to technical defaults versus outright defaults.

The question remains however, with which party does the adverse selection lie? Our empirical results uncovered the predicted negative relationship between haircuts and rates only for securities-in transactions. Potentially then, the adverse selection could come from the probabilities of dealers' counterparties not returning the cash on the agreed-upon date, or the dealers' probabilities of failing to return the securities. This second source is most likely, as 
creditworthy firms usually have multiple ways of accessing the market for cash borrowing in contrast to sourcing securities that are potentially in scarce supply.

Our results, combined with the institutional details of the market, imply that market participants are concerned about securities dealers' probabilities of failing to return borrowed securities. The use of collateral as a screening mechanism is a tool to separate securities dealers that are more and less likely to fail to return the borrowed securities on the agreed-upon date.

Although we link our empirical results on the negative relationship between spread and haircut to the adverse selection literature, we acknowledge that other theories relevant to the securities financing market may also predict the same negative relationship. In particular, Kuong (2016) generates this prediction using a model of moral hazard where assets posted as collateral can be financial in nature. It would be interesting to test whether adverse selection or moral hazard is the more salient force in the bilateral repo market, although our understanding is that such analysis requires detailed data on fails, which we do not have.

The negative relationship between haircuts and rates is also a common feature of general equilibrium models of collateral. This implication stems from the fact that lower haircuts usually reduce the cash lender's payoff in certain states of the world. To offset this increase in risk, the lender asks for a higher interest rate on the cash.

\section{Conclusion}

This paper analyzes the bilateral securities financing market, an important U.S. financial market. We describe a novel data set of bilateral securities financing transactions, which provide a representative view of this opaque market. In addition to providing stylized facts about the market, we analyze the role of collateral. We first test the implications of zero value-at-risk, a feature that is common to theories of collateral where collateral is an enforcement mechanism. We find mixed results for the zero value-at-risk prediction that haircuts are set to prevent default and that they are only a function of an individual asset's (CUSIP) characteristics, suggesting that although the enforcement mechanism of collateral is important, other factors are likely to be driving forces in determining haircuts. We also highlight that haircut setting behavior differs by asset class, suggesting that different underlying economic forces are at play across asset classes. 
Finally, we focus on transactions involving U.S. Treasuries and consider the role of collateral as a screening mechanism, which can be used by market participants to mitigate the effects of adverse selection. In the data, we find evidence of such a mechanism for trades where dealers receive U.S. Treasuries, but not for trades where dealers deliver them. 


\section{Bibliography}

Adrian, Tobias, Brian Begalle, Adam Copeland, and Antoine Martin, 2013. "Repo and Securities Lending,” Risk Topography: Systemic Risk and Macro Modeling. Eds Markus Brunnermeier and Arvind Krishnamurthy. Chicago: Univeristy of Chicago Press, pages 131-148.

Alkan, Leyla, Vic Chakrian, Adam Copeland, Isaac Davis, and Antoine Martin, 2013. "Magnifying the Risk of Fire-Sales in the Tri-Party Repo Market,” Liberty Street Economics blog, July 17.

Auh, Jun Kyung, and Mattia Landoni. 2016. “Loan Terms and Collateral: Evidence from the Bilateral Repo Market,” Manuscript.

Ayotte, Kenneth and David Skeel. 2009. “Bankruptcy or Bailouts?” Faculty Scholarship. Paper 259.

Baklanova, Viktoria, Cecilia Caglio, Frank Keane, and Burt Porter. 2016a. “A Pilot Survey of Agency Securities Lending Activity,” Federal Reserve Bank of New York Staff Report 790.

Baklanova, Viktoria, Cecilia Caglio, Marco Cirpriani, and Adam Copeland. 2016b. “The U.S. Bilateral Repo Market: Lessons from a New Survey,” OFR Brief Series 16-01.

Baklanova, Viktoria, Adam Copeland, and Rebecca McCaughrin, 2015. "Reference Guide to U.S. Repo and Securities Lending Markets,” OFR Working Paper 15-17.

Berger, Allen, Marco Espinosa-Vega, W. Scott Frame, and Nathan Miller. 2011(a). "Why do borrowers pledge collateral? New empirical evidence on the role of asymmetric information,” Journal of Financial Intermediation, vol. 20, pages 55-70.

Berger, Allen, W. Scott Frame, and Vasso Ioannidou. 2011(b). "Tests of ex ante versus ex post theories of collateral using private and public information,” Journal of Financial Economics vol. 100, pages 85-97.

Berry, Steve. 1994. “Estimating Discrete-Choice Models of Product Differentiation,” Rand Journal of Economics, vol. 25, pages 242-262.

Berry, Steve, James Levinsohn, and Ariel Pakes. 1995. “Automobile Prices in Market Equilibrium,” Econometrica, vol. 63, pages 841-890. 
Bester, Helmut. 1985. "Screening vs. Rationing in Credit Markets with Imperfect Information.” American Economic Review, vol. 75(4), pages 850-855.

Besanko, David, and AnjanV. Thakor. 1987a. "Collateral and rationing: sorting equilibria in monopolistic and competitive credit markets” International Economic Review, 28(3), pp. 671-689.

Besanko, David and Anjan V. Thakor. 1987b. “Competitive equilibria in the credit market under asymmetric information,” Journal of Economic Theory, 42, pp. 167-182.

Bonaldi, Pietro. 2017. "Motives and Consequences of Libor Misreporting: How Much Can We Learn from Banks’ Misleading Submissions?” Manuscript.

Bresnahan, Timothy. 1981. "Departures from Marginal-Cost Pricing in the American Automobile Industry,” Journal of Econometrics, vol. 17, pages 201-227.

Brunnermeier, Markus, and Lasse Pedersen. 2009. "Market Liquidity and Funding Liquidity,” Review of Financial Studies, vol. 22(6), pages 2201-2238.

Buraschi, Andrea and Davide Menini. 2002. “Liquidity risk and specialness,” Journal of Financial Economics 64, pages 243-284.

Chan, Yuk-See and George Kanatas. 1985. “Asymmetric valuation and the role of collateral in loan agreements,” Journal of Money, Credit and Banking, 17, pp. 85-95

Chan Yuk-See, Stuart Greenbaum, and Anjan V. Thakor. 1986. “Information reusability, competition and bank asset quality,” Journal of Banking and Finance, 10(2), pp. 243-253

Cerqueiro. Geraldo, Steven Ongena, and Kasper Roszbach. 2016. “Collateralization, Bank Loan Rates, and Monitoring,” Journal of Finance, vol. 71(3), pages 1295-1322.

Copeland, Adam, Isaac Davis, Eric LeSueur, and Antoine Martin, 2014a. "Lifting the Veil on the U.S. Bilateral Repo Market,” Federal Reserve Bank of New York Liberty Street Economics blog, July 9, 2014.

Copeland, Adam, Antoine Martin, and Michael Walker. 2014b. "Repo Runs: Evidence from the Triparty Repo Market,” The Journal of Finance, vol. 69(6), pages 2343-2380. 
Copeland, Adam, Antoine Martin, and Michael Walker. 2010. “The Tri-Party Repo Market before the 2010 Reforms,” Federal Reserve Bank of New York Staff Report 477.

Cornelissen, Thomas. 2008. "The Stata command felsdvreg to fit a linear model with two highdimensional fixed effects,” The Stata Journal 8(2), pages 170-189.

D’Amico, Stefania, Roger Fan, and Yuriy Kitsul, 2013. "The Scarcity Value of Treasury Collateral: Repo Market Effects of Security-Specific Supply and Demand Factors,” Federal Reserve Bank of Chicago working paper WP 2013-22.

Duffie, Darrell. 1996. “Special Repo Rates” Journal of Finance, vol. 51(2), pages 493-526.

Duffie, Darrell, and David Skeel. 2012. “A Dialogue on the Costs and Benefits of Automatic Stays for Derivatives and Repurchase Agreements,” Faculty Scholarship. Paper 386.

Evans, Richard, Christopher Geczy, David Musto, and Adam Reed. 2009. "Failure Is an Option: Impediments to Short Selling and Options Prices,” Review of Financial Studies, vol. 22(5), pages 1955-1980.

Fleming, Michael J. and Kenneth D. Garbade. 2005. “Explaining Settlement Fails,” FRBNY Current Issues in Economics and Finance, vol. 11(9).

Fleming, Michael J. and Kenneth D. Garbade, 2007. "Dealer behavior in the specials market for U.S. Treasury securities.” Journal of Financial Intermediation 16(2), pages 204-228.

Fostel, Ana and John Geanakoplos. 2015. "Leverage and Default in Binomial Economies: A Complete Characterization.” Econometrica, vol. 83(6), pages 2191-2229.

Garbade, Kenneth. 2006. "The Evolution of Repo Contracting Conventions in the 1980s.” FRBNY Economic Policy Review, May, pages 27-42.

Garbade, Kenneth, Frank Keane, Lorie Logan, Amanda Stokes, and Jennifer Wolgemuth. 2010. “The Introduction of the TMPG Fails Charge for U.S. Treasury Securities,” FRBNY Economic Policy Review, October, pages 45-71.

Garleanu, Nicolae, and Lasse Pedersen. 2011. "Margin-Based Asset Pricing and Deviations from the Law of One Price,” Review of Financial Studies, vol 24(6), pages 1980-2022.

Geanakoplos, John. 2003. "Liquidity, Default, and Crashes: Endogenous Contracts in General Equilibrium," Advances in Economics and Econometrics: Theory and Applications, 
Eighth World Conference, Volume II, Econometric Society Monographs (2003), pp. 170205. [CFDP 1316RR and CFP 1074]

Geanakoplos, John. 2010. “The Leverage Cycle.” In D. Acemoglu, K. Rogoff and M. Woodford, eds., NBER Macroeconomic Annual 2009, vol. 24: 1-65, University of Chicago Press, 2010 [plus erratum] [CFP 1304]

Gong, Feixue and Gregory Phelan, 2017, "Debt Collateralization, Capital Structure, and Maximal Leverage,” mimeo.

Gong, Feixue and Gregory Phelan, 2017, "Debt Collateralization, Structured Finance, and the CDS Basis,” mimeo.

Godlewski, Christophe, and Laurent Weill. 2011. "Does Collateral Help Mitigate Adverse Selection? A Cross-Country Analysis,” Journal of Financial Services Research, vol. 40, pages 49-78.

Gorton, Gary, and Andrew Metrick. 2012 "Securitized Banking and the Run on Repo." Journal of Financial Economics, vol. 104(3).

Gromb, Dines and Dimitri Vayanos. 2002. "Equilibrium and Welfare in Markets with Financially Constrained Arbitrageurs,” Journal of Financial Economics, vol. 66, pages 361-407.

Hu, Grace Xing, Jun Pan, and Jiang Wang. 2015. “Tri-Party Repo Pricing,” Manuscript.

Jordan, Bradford and Susan Jordan. 1997. "Special repo rates: An empirical analysis.” Journal of Finance 52(5), pages 2051-2072.

Kiyotaki, Nobuhiro, and John Moore. 1997. “Credit Cycles,” Journal of Political Economy, vol. 105(2), pages 211-248.

Keane, Frank. 2013. "Securities Loans Collateralized by Cash: Reinvestment Risk, Run Risk, and Incentive Issues,” Federal Reserve Bank of New York Current Issues, vol 19(3).

Krishnamurthy, Arvind, Stefan Nagel, and Dmitry Orlov, 2014. “Sizing Up Repo,” Journal of Finance, vol. 69(6), pages 2381-2417.

Kuong, John C.F. 2016. "Self-fulfilling Fire Sales: Fragility of Collateralized Short-term Debt Markets.” INSEAD manuscript. 
Lipson, Paul, Bradley Sabel, and Frank Keane. 2012. “Securities Lending,” Federal Reserve Bank of New York Staff Report 555.

Martin, Antoine, David Skeie, and Ernst-Ludwig von Thadden. 2014. “Repo Runs,” Review of Financial Studies, vol 27(4), pages 957-989.

Morrison, Edward, Mark Roe, and Christopher Sontchi. 2014. "Rolling Back the Repo Safe Harbors,” Business Lawyer, vol. 69.

Nevo, Aviv. 2000. "Measuring Market Power in the Ready-to-Eat Cereal Industry," Econometrica, vol 69(2), pages 307-342.

Peirce, H. 2014. "Securities lending and the Untold Story in the Collapse of AIG," George Mason University, Mercatus Center Working Paper No. 14-12.

Snide Connan, and Thomas Youle. 2014. "The Fix is In: Detecting Portfolio Driven Manipulation of the Libor.” Manuscript. 


\section{Tables}

Table 1: Summary Statistics

\begin{tabular}{|c|c|c|c|c|c|c|}
\hline \multirow[b]{2}{*}{ Date } & \multicolumn{2}{|c|}{$\begin{array}{l}\text { Value Transacted } \\
\text { (\$ billions) }\end{array}$} & Number & f Trades & \multicolumn{2}{|c|}{$\begin{array}{c}\text { Pilot as a Percent of } \\
\text { Total Bilateral Repo } \\
\text { Market } \\
\text { Securities }\end{array}$} \\
\hline & In & Out & In & Out & In & Out \\
\hline 12-Jan-15 & 1,574 & 921 & 486,433 & 209,095 & 52 & 51 \\
\hline 10-Feb-15 & 1,648 & 969 & 511,254 & 202,432 & 54 & 53 \\
\hline 10-Mar-15 & 1,693 & 986 & 518,466 & 187,503 & 53 & 53 \\
\hline Average & 1,639 & 958 & 505,384 & 199,677 & 53 & 52 \\
\hline
\end{tabular}

Notes: "Securities In" is a transaction in which the reporting dealer received securities and "Securities Out" is a transaction in which the reporting dealer delivered securities. Share calculations are the ratio of value transacted in the bilateral repo pilot over the bilateral repo segment estimates presented in Table B in the Appendix.

Sources: Bilateral Repo Data Collection Pilot, authors’ calculations. 
Table 2: Securities Lending Transactions as a Percent of Total, by Asset Class (percent)

\begin{tabular}{l|cc}
\multirow{2}{*}{ Asset Class } & \multicolumn{2}{|c}{ Value-Weighted } \\
& \multicolumn{2}{|c}{ Securities } \\
In & Out \\
\hline U.S. Treasuries & 27.2 & 3.7 \\
Equities & 99.9 & 100.0 \\
Private-Label CMO, MBS, ABS & 7.4 & d \\
Corporate & 75.7 & 55.5 \\
Other Agency & 3.6 & - \\
Municipality Debt & 5.0 & d \\
Agency MBS & 4.7 & - \\
Other & d & d \\
All asset classes & 43.0 & 19.8
\end{tabular}

Notes: Each transaction in the data is documented as a repurchase agreement or a securities lending contract. Each element in the table reports the share of securities lending contracts as a percent. Asset classes are ordered from largest to smallest in terms of principal value. "Securities In" is a transaction in which the reporting dealer received securities and "Securities Out" is a transaction where the reporting dealer delivered securities. "d" means the number is suppressed so as to not reveal an individual dealer's information. CMO is collateralized mortgage obligation, MBS is mortgage-backed securities, and ABS is asset-backed securities.

Sources: Bilateral Repo Data Collection Pilot, authors' calculations. 
Table 3: Securities In- and -Out by Asset Class

\begin{tabular}{|c|c|c|c|c|}
\hline \multirow[t]{2}{*}{ Asset Class } & \multicolumn{2}{|c|}{$\begin{array}{l}\text { Principal Value } \\
\text { (\$ billions) } \\
\text { Securities }\end{array}$} & \multicolumn{2}{|c|}{$\begin{array}{l}\text { Value-weighted Shares } \\
\text { (percent) } \\
\text { Securities }\end{array}$} \\
\hline & In & Out & In & Out \\
\hline U.S. Treasuries & 711,539 & 416,408 & 61.4 & 81.0 \\
\hline Equities & 244,421 & 78,912 & 21.1 & 15.3 \\
\hline Private-Label CMO, MBS, ABS & 110,162 & 3,434 & 9.5 & 0.7 \\
\hline Corporate & 76,665 & 15,183 & 6.6 & 3.0 \\
\hline Other Agency & 13,677 & $\mathrm{~d}$ & 1.2 & d \\
\hline Municipality Debt & 1,121 & - & 0.1 & - \\
\hline Agency MBS & $\mathrm{d}$ & $\mathrm{d}$ & $\mathrm{d}$ & $\mathrm{d}$ \\
\hline Other & $\mathrm{d}$ & $\mathrm{d}$ & $\mathrm{d}$ & $\mathrm{d}$ \\
\hline Total & $1,158,598$ & 514,253 & 100.0 & 100.0 \\
\hline
\end{tabular}

Notes: "Securities In" is a transaction in which the reporting dealer received securities and "Securities Out" is a transaction in which the reporting dealer delivered securities. Asset classes are ordered from largest to smallest in terms of principal value. "d" means the number is suppressed so as to not reveal an individual dealer's information. $\mathrm{CMO}$ is collateralized mortgage obligation, MBS is mortgage-backed securities, and ABS is asset-backed securities. Sources: Bilateral Repo Data Collection Pilot, authors’ calculations. 
Table 4: Maturities by Asset Class

\begin{tabular}{|c|c|c|c|c|}
\hline \multirow[t]{2}{*}{ Maturity } & \multicolumn{3}{|c|}{$\begin{array}{l}\text { Value-weighted Share } \\
\text { (percent) }\end{array}$} & \multirow[b]{2}{*}{ All Other } \\
\hline & U.S. Treasuries & Equities & Corporate debt & \\
\hline Open & 14.4 & 90.1 & 75.6 & 10.3 \\
\hline Overnight & 29.8 & - & 3.3 & 11.5 \\
\hline 1 day $<$ tenor $<=7$ days & 6.8 & - & 1.9 & 0.8 \\
\hline 7 days $<=$ tenor $<30$ days & 13.7 & 0.1 & 2.4 & 9.5 \\
\hline 30 days $<$ tenor $<=1$ year & 15.7 & 3.6 & 10.2 & 43.1 \\
\hline tenor $>1$ year & 19.5 & 6.2 & 6.7 & 24.8 \\
\hline
\end{tabular}

Notes: Each column sums to 100. For trades with maturity optionality such as a put or call, tenor is equal to the notice period.

Sources: Bilateral Repo Data Collection Pilot, authors’ calculations 
Table 5: Value-Weighted Overnight Interest Rates (percent)

\begin{tabular}{l|rrrrrrr}
\multicolumn{1}{c|}{ Asset Class } & \multicolumn{2}{c}{ Securities In } & \multicolumn{2}{c}{ Securities Out } & \multicolumn{2}{c}{ Both In and Out } \\
& Mean & Median & Mean & Median & Mean & Median \\
\hline U.S. Treasuries & 0.04 & 0.11 & -0.01 & 0.06 & 0.02 & 0.09 \\
Equities & -0.98 & 0.03 & -0.55 & 0.04 & -0.88 & 0.03 \\
Private-Label CMO, MBS, ABS & 0.38 & 0.20 & 0.10 & 0.06 & 0.29 & 0.20 \\
Corporate & -0.21 & 0.03 & -0.53 & 0.03 & -0.26 & 0.03 \\
Other Agency & 0.20 & 0.21 & - & - & 0.20 & 0.21 \\
Municipality Debt & 0.54 & 0.60 & $\mathrm{~d}$ & $\mathrm{~d}$ & $\mathrm{~d}$ & $\mathrm{~d}$ \\
Agency MBS & 0.17 & 0.17 & - & - & 0.17 & 0.17 \\
Other & $\mathrm{d}$ & $\mathrm{d}$ & $\mathrm{d}$ & $\mathrm{d}$ & $\mathrm{d}$ & $\mathrm{d}$ \\
Average & -0.38 & 0.07 & -0.15 & 0.05 & -0.31 & 0.07
\end{tabular}

Notes: : "Securities In" is a transaction in which the reporting dealer received securities, "Securities Out" is a transaction in which the reporting dealer delivered securities, and "Both In and Out" includes both securities-in and securities-out. Asset classes are ordered from largest to smallest in terms of principal value. For some of the trades we do not have interest rate information; we omit interest rate data submitted by one respondent because of dataquality issues. "d" means the number is suppressed so as to not reveal an individual dealer's information. CMO is collateralized mortgage obligation, MBS is mortgage-backed securities, and ABS is asset-backed securities.

Sources: Bilateral Repo Data Collection Pilot, authors’ calculations. 
Table 6: Value-Weighted Percent of Trades by Haircut Bin, Asset Class, and Transaction Type

\begin{tabular}{|c|c|c|c|c|c|c|c|c|}
\hline \multirow[t]{2}{*}{ Asset Class } & \multirow{2}{*}{$\begin{array}{c}\text { Securities } \\
\text { In or } \\
\text { Out? }\end{array}$} & \multicolumn{7}{|c|}{ Haircut Bins } \\
\hline & & $<-2$ & {$[-2,-1)$} & {$[-1,0)$} & 0 & $(0,1]$ & {$[1,2)$} & $>2$ \\
\hline \multirow[t]{2}{*}{ U.S. Treasuries } & In & 7.1 & 14.0 & 0.1 & 66.6 & 10.1 & 1.5 & 0.6 \\
\hline & Out & 1.4 & 0.8 & 3.3 & 76.0 & 11.3 & 4.6 & 2.6 \\
\hline \multirow[t]{2}{*}{ Equities } & In & 2.9 & 76.9 & 0.0 & 12.8 & 0.0 & 0.0 & 7.4 \\
\hline & Out & 0.1 & 65.9 & 0.0 & 30.5 & 0.0 & 0.1 & 3.4 \\
\hline \multirow{2}{*}{$\begin{array}{c}\text { Private-Label CMO, } \\
\text { MBS, ABS }\end{array}$} & In & 5.0 & 0.7 & 0.0 & 0.3 & 0.6 & 0.2 & 93.2 \\
\hline & Out & 10.2 & 0.0 & 0.0 & 12.1 & 1.4 & 28.8 & 47.6 \\
\hline \multirow[t]{2}{*}{ Corporate } & In & 6.0 & 43.8 & 0.5 & 12.5 & 1.4 & 1.0 & 34.8 \\
\hline & Out & 3.0 & 40.5 & 0.4 & 29.7 & 0.7 & 1.7 & 23.9 \\
\hline \multirow[t]{2}{*}{ Other Agency } & In & 0.0 & 0.0 & 0.0 & 1.1 & 0.0 & 0.0 & 98.9 \\
\hline & Out & 0.0 & 0.0 & 0.0 & 21.2 & 0.0 & 0.0 & 78.8 \\
\hline \multirow[t]{2}{*}{ Municipality Debt } & In & 0.0 & 2.4 & 0.6 & 0.5 & 0.2 & 0.1 & 96.3 \\
\hline & Out & 100.0 & 0.0 & 0.0 & 0.0 & 0.0 & 0.0 & 0.0 \\
\hline \multirow[t]{2}{*}{ Agency MBS } & In & 0.0 & 0.0 & 0.0 & 0.3 & 0.0 & 0.0 & 99.7 \\
\hline & Out & - & - & - & - & - & - & - \\
\hline \multirow[t]{2}{*}{ Other } & In & - & - & - & - & - & - & - \\
\hline & Out & - & - & - & - & - & - & - \\
\hline \multirow[t]{2}{*}{ Total } & In & 6.5 & 26.4 & 0.1 & 45.4 & 6.0 & 1.0 & 14.7 \\
\hline & Out & 1.2 & 11.4 & 2.4 & 69.6 & 8.3 & 3.6 & 3.4 \\
\hline
\end{tabular}

Notes: "Securities In" is a transaction in which the reporting dealer received securities and "Securities Out" is a transaction in which the reporting dealer delivered securities. Asset classes are ordered from largest to smallest in terms of principal value. The haircut bin labels denote the endpoints of a bucket, where ")" means the endpoint is not included and "]" means the endpoint is included. "<-2" indicates all haircuts strictly less than -2 and " $>2$ " indicates all haircuts strictly greater than 2. CMO is collateralized mortgage obligation, MBS is mortgage-backed securities, and ABS is asset-backed securities.

Sources: Bilateral Repo Data Collection Pilot, authors’ calculations. 
Table 7: Concentration of Activity at the Modal Value of Haircuts by Asset Class

\begin{tabular}{l|cc} 
Asset Class & $\begin{array}{l}\text { Haircut } \\
\text { Mode } \\
\text { (percent) }\end{array}$ & $\begin{array}{l}\text { Share of } \\
\text { Total } \\
\text { Activity } \\
\text { (percent) }\end{array}$ \\
\hline U.S. Treasuries & 0 & 70 \\
Equities & -2 & 79 \\
Private-Label CMO, MBS, ABS & 5 & 14 \\
Corporate & -2 & 55 \\
Other Agency & 25 & 26 \\
Municipality Debt & 15 & 21 \\
Agency MBS & 7 & 34 \\
Other & -2 & 100
\end{tabular}

Notes: Asset classes are ordered from largest to smallest in terms of principal value. CMO is collateralized mortgage obligation, MBS is mortgage-backed securities, and ABS is asset-backed securities.

Sources: Bilateral Repo Data Collection Pilot, authors' calculations. 
Table 8: Distribution of Number of Haircuts per CUSIP

\begin{tabular}{|c|c|c|c|c|c|c|c|c|c|c|}
\hline \multirow[t]{2}{*}{$\begin{array}{l}\text { Haircut } \\
\text { Sign }\end{array}$} & \multirow[t]{2}{*}{ Asset Class } & \multirow[t]{2}{*}{ Mean } & \multirow[t]{2}{*}{ Std } & \multicolumn{6}{|c|}{ Percentiles } & \multirow[t]{2}{*}{ Obs } \\
\hline & & & & 10 & 25 & 50 & 75 & 90 & 95 & \\
\hline \multirow{3}{*}{ Positive } & U.S. Treasuries & 3.73 & 3.56 & 1 & 1 & 2 & 5 & 8 & 12 & 5,938 \\
\hline & Equities & - & - & - & - & - & - & - & - & - \\
\hline & Corporate & 1.10 & 0.33 & 1 & 1 & 1 & 1 & 1 & 2 & 2,087 \\
\hline \multirow{3}{*}{ Negative } & U.S. Treasuries & 2.46 & 1.24 & 1 & 2 & 2 & 3 & 4 & 4 & 17,307 \\
\hline & Equities & 1.09 & 0.29 & 1 & 1 & 1 & 1 & 1 & 2 & $1,006,559$ \\
\hline & Corporate & 1.06 & 0.35 & 1 & 1 & 1 & 1 & 1 & 1 & 129,989 \\
\hline
\end{tabular}

Notes: "Std" is standard deviation. Excluded observations include affiliated trades, those with small principal amounts, and those with zero haircuts. Small principal amounts for U.S. Treasuries, equities, and corporate debt securities are those less than $\$ 100, \$ 10$, and $\$ 100$, respectively. Finally, only overnight or open trades are included. Sources: Bilateral Repo Data Collection Pilot, authors’ calculations. 
Table 9: Value-Weighted Percent of Activity with Securities Associated with Multiple Haircuts

\begin{tabular}{cl|ccc}
$\begin{array}{c}\text { Haircut } \\
\text { Sign }\end{array}$ & Asset Class & \multicolumn{3}{|c}{ Transaction type } \\
& & $\begin{array}{c}\text { All } \\
\text { Securities }\end{array}$ & Securities In & Securities Out \\
\hline \multirow{3}{*}{ Positive } & U.S. Treasuries & $81 \%$ & $85 \%$ & $78 \%$ \\
& Equities & - & - & - \\
& Corporate & $9 \%$ & $9 \%$ & $1 \%$ \\
& & & & $95 \%$ \\
Negative & Equities & $40 \%$ & $89 \%$ & $4 \%$ \\
& Corporate & $15 \%$ & $18 \%$ & $2 \%$
\end{tabular}

Notes: All Securities includes all trades, whereas “Securities In” only includes those trades in which the reporting dealer received securities and "Securities Out" only includes those trades in which the reporting dealer delivered securities. Excluded observations include affiliated trades, those with small principal amounts, and those with zero haircuts. Small principal amounts for U.S. Treasuries, equities, and corporate debt securities are those less than $\$ 100$, \$10, and \$100, respectively. Finally, only overnight or open trades are included.

Sources: Bilateral Repo Data Collection Pilot, authors’ calculations. 
Table 10: Comparison of the Haircut and Expected Price Jump

\begin{tabular}{|c|c|c|c|c|}
\hline \multirow[t]{2}{*}{ Haircut Sign } & \multirow[t]{2}{*}{ Asset Class } & \multirow[t]{2}{*}{$\begin{array}{l}\text { Percent } \\
\text { Safe }\end{array}$} & \multicolumn{2}{|c|}{$\begin{array}{c}\text { Correlation between Haircut and Expected } \\
\text { Price Jump }\end{array}$} \\
\hline & & & Pairwise correlation & Regression coefficient \\
\hline \multirow{3}{*}{ Positive } & $\begin{array}{l}\text { U.S. } \\
\text { Treasuries }\end{array}$ & 80 & $-0.201 * * *$ & $-23.5 * *$ \\
\hline & Equities & - & - & - \\
\hline & Corporate & 79 & $-0.125 * * *$ & $-50.1 * * *$ \\
\hline \multirow{3}{*}{ Negative } & $\begin{array}{l}\text { U.S. } \\
\text { Treasuries }\end{array}$ & 91 & $-0.192 * * *$ & -4.6 \\
\hline & Equities & 22 & $-0.043 * * *$ & $-0.04 * *$ \\
\hline & Corporate & 72 & -0.002 & -0.0 \\
\hline
\end{tabular}

Note: Percent Safe is the percent of (haircut, CUSIP) pairs where the absolute value of the haircut is larger than the absolute value of the expected price jump. For positive haircuts, we use the expected price decrease, and for negative haircuts, we use the expected price increase. For trades with positive (negative) haircuts, the pairwise correlation is between the haircut and the expected price decrease (increase). ${ }^{* *}$ and $* * *$ denote statistical significance at the 95 and 99 confidence level, respectively. The dependent variable in the regression is the haircut and the independent variables are the expected price decrease/increase, the log of the principal amount and fixed effects for each dealer and counterparty. In the regression, standard errors are clustered by dealer and counterparty. Excluded observations include affiliated trades, those with small principal amounts, and those with zero haircuts. Small principal amounts for U.S. Treasuries, equities and corporate debt securities are those less than $\$ 100, \$ 10$, and $\$ 100$, respectively. Finally, only overnight or open trades are included.

Sources: Bilateral Repo Data Collection Pilot, authors’ calculations. 
Table 11: Summary of results for implications of zero value-at-risk

\begin{tabular}{|c|c|c|c|}
\hline Asset Classes & $\begin{array}{c}\text { Single Haircut per } \\
\text { CUSIP? }\end{array}$ & $\begin{array}{c}\text { Negative correlation } \\
\text { between rates and } \\
\text { price distribution? }\end{array}$ & $\begin{array}{c}\text { Are haircuts large } \\
\text { enough to protect } \\
\text { against default? }\end{array}$ \\
\hline U.S. Treasuries & $\begin{array}{l}\text { No. The vast majority of } \\
\text { CUSIPS associated with } \\
\text { multiple haircuts }\end{array}$ & Mixed results. & Yes \\
\hline Equities & Yes & $\begin{array}{l}\text { No. Estimated correlation } \\
\text { is not economically } \\
\text { significant. }\end{array}$ & $\begin{array}{l}\text { No. Haircuts are only } \\
\text { large enough for } 22 \\
\text { percent of transactions. }\end{array}$ \\
\hline Corporates & Yes & $\begin{array}{l}\text { No. Estimated correlation } \\
\text { is not statistically } \\
\text { significant for negative } \\
\text { haircut trades, which } \\
\text { account for the vast } \\
\text { majority of transactions }\end{array}$ & Yes \\
\hline
\end{tabular}

Note: This table summarizes the results where three implications of the zero value-at-risk feature are empirically tested. For all three implications, the zero value-at-risk feature predicts a "yes” response.

Sources: Bilateral Repo Data Collection Pilot, authors' calculations. 
Table 12: Estimated Impact of Haircuts on Spreads (U.S. Treasuries)

\begin{tabular}{|c|c|c|c|c|c|}
\hline $\begin{array}{c}\text { Transaction } \\
\text { Type }\end{array}$ & Coefficient & \multicolumn{2}{|c|}{ OLS } & & \\
\hline \multirow{4}{*}{ Securities In } & haircut & -0.0050 & $(0.0084)$ & $-0.117 * *$ & $(0.1020)$ \\
\hline & $\ln ($ principal) & $-0.0035 * * *$ & $(0.0003)$ & $-0.0036 * * *$ & $(0.0003)$ \\
\hline & tenor & -0.0000 & $(0.0001)$ & 0.0000 & $(0.0001)$ \\
\hline & tenor_sq & $0.0000 * * *$ & $(0.0000)$ & $-0.0000 * * *$ & $(0.0000)$ \\
\hline Observations & & \multicolumn{2}{|c|}{15,022} & \multicolumn{2}{|c|}{15,022} \\
\hline \multirow[t]{4}{*}{ Securities Out } & haircut & $0.0131 * *$ & $(0.0068)$ & 0.0191 & $(0.0135)$ \\
\hline & $\ln ($ principal) & $-0.0031^{* * *}$ & $(0.0002)$ & $-0.0032 * * *$ & $(0.0004)$ \\
\hline & tenor & $0.0007 * * *$ & $(0.0002)$ & $0.0007 * * *$ & $(0.0002)$ \\
\hline & tenor_sq & $0.0000 * * *$ & $(0.0000)$ & $0.0000 * * *$ & $(0.0000)$ \\
\hline Observations & & \multicolumn{2}{|c|}{4,927} & \multicolumn{2}{|c|}{4,927} \\
\hline
\end{tabular}

Note: tenor_sq is the square of the tenor of the trade, and $\ln$ (principal) is the log of the principal amount. Zero haircut, affiliated, and small principal trades have been dropped. Small principal amounts for U.S. Treasuries, equities and corporate debt securities are those less than $\$ 100, \$ 10$, and $\$ 100$, respectively. OLS is ordinary least squares and IVLS is instrumental variables least squares. The dependent variable is the spread between the negotiated rate and the LIBOR with equivalent maturity. Included in each regression, but not reported, are fixed effects for each (dealer, counterparty) pair and CUSIP. ** and *** denote statistical significance at the 95 and 99 confidence level, respectively. Bootstrapped standard errors are in parenthesis.

Sources: Bilateral Repo Data Collection Pilot, authors' calculations. 


\section{Figures}

Figure 1: Value-weighted Share of Activity by Counterparty Type

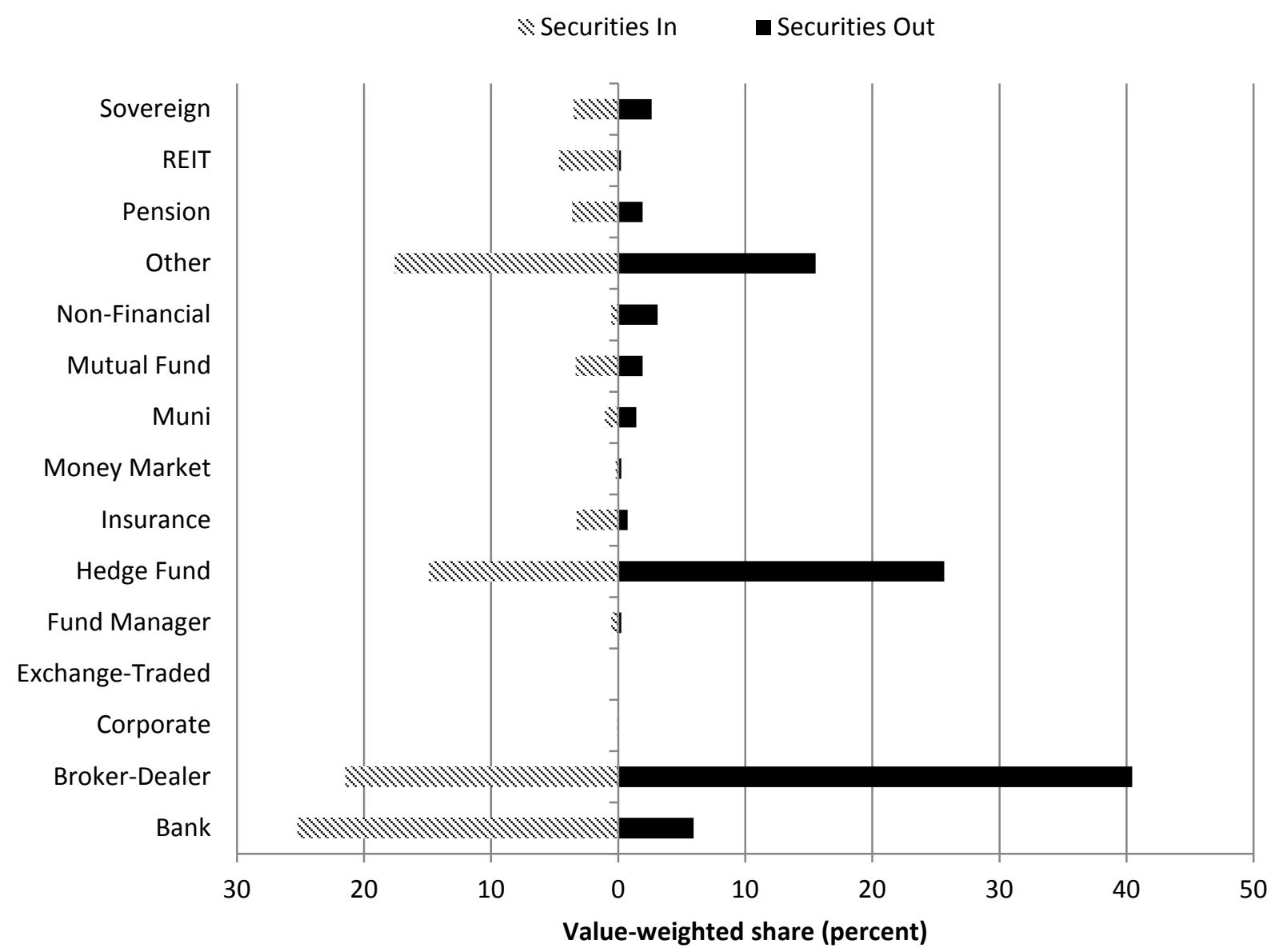

Notes: REIT is real-estate investment trust and Muni is municipal bonds. Counterparty type is reported by respondent.

Sources: Bilateral Repo Data Collection Pilot, authors’ calculations. 
Figure 2: Distribution of Interest Rates for U.S. Treasuries Transactions (Open and Overnight Maturities)

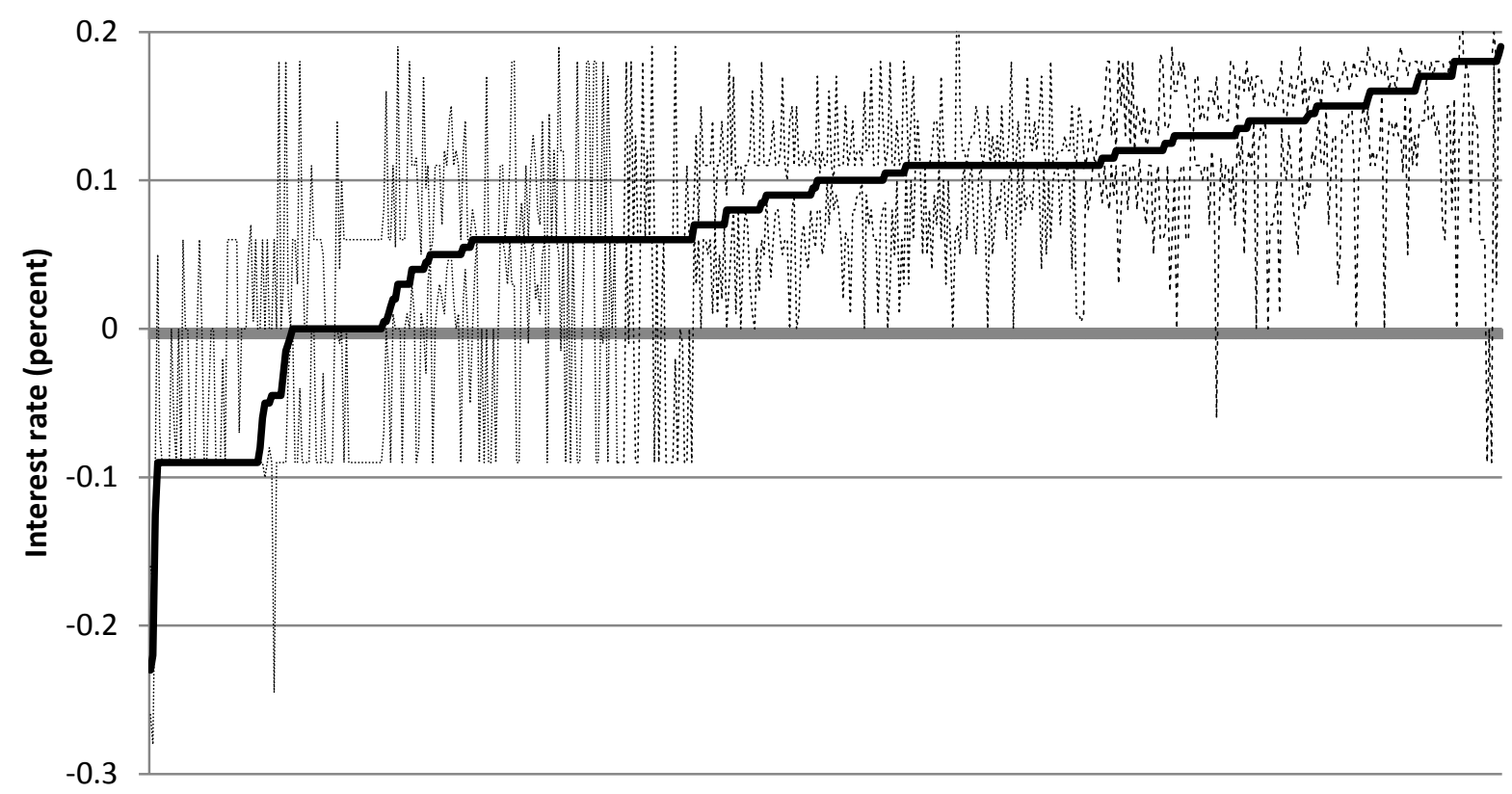

Note: The solid line is the median rate for a bilateral trade by CUSIP on February 10, 2015. CUSIPs are sorted left to right by the median rate. The dotted lines above and below the solid line are the $25^{\text {th }}$ and $75^{\text {th }}$ percentile of the interest rate distribution for a CUSIP on February 10th. On this date, the general collateral interest rate for a funding transaction collateralized by U.S. Treasuries was 0.054 percent.

Sources: Bilateral Repo Data Collection Pilot, Bank of New York Mellon (BNYM) Tri-Party Repo Index, authors' calculations. 
Figure 3: Maturity Profile of US Treasuries Transactions’ Spreads to USD LIBOR.

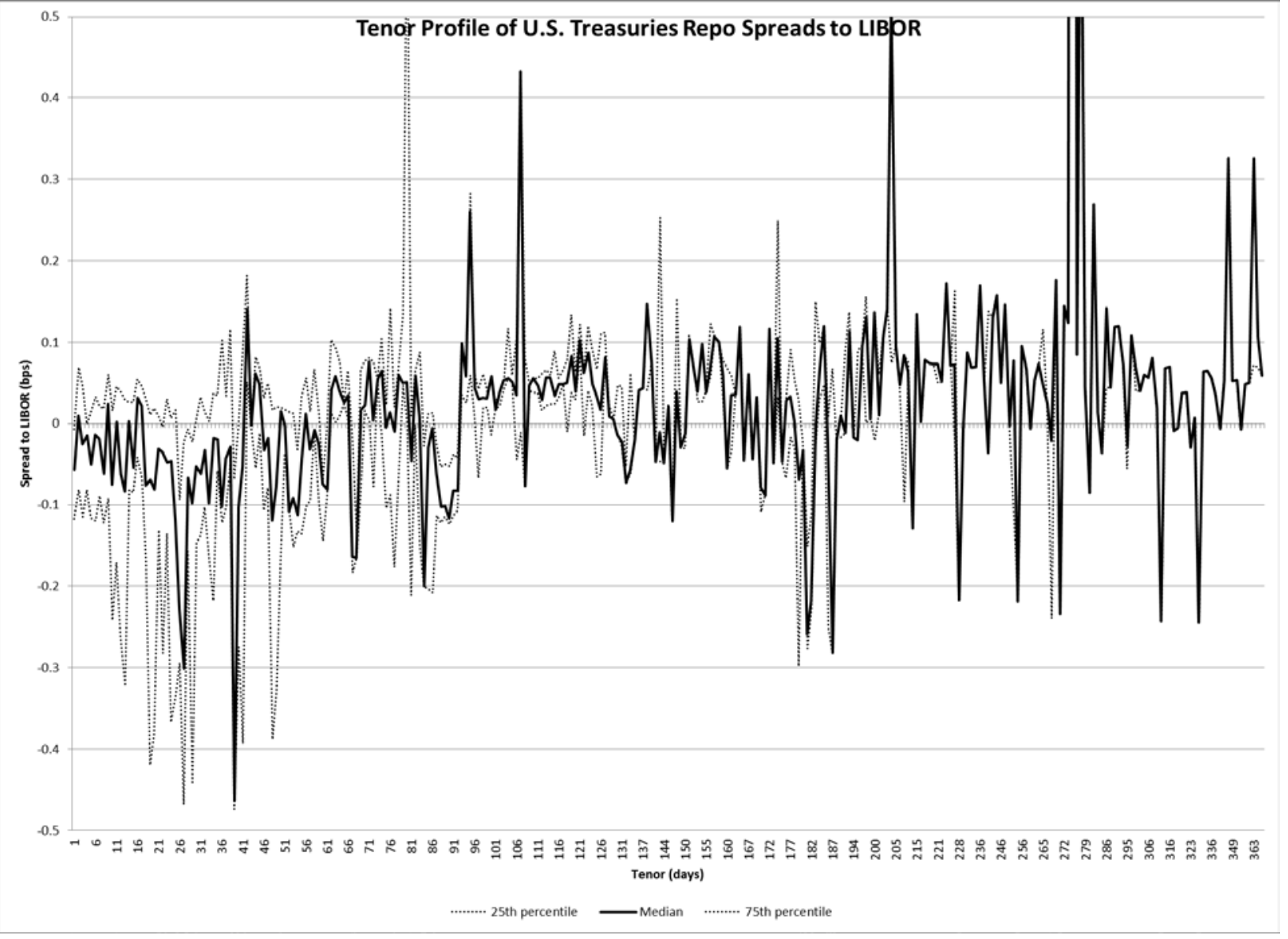

Note: The solid line is the median spread from USD LIBOR for a bilateral trade by maturity. The dotted lines above and below the solid line are the $25^{\text {th }}$ and $75^{\text {th }}$ percentile of the spread distribution by maturity Sources: Bilateral Repo Data Collection Pilot, authors’ calculations. 
Figure 4: Variation in Haircuts and Potential Price Increases for Equities Trades

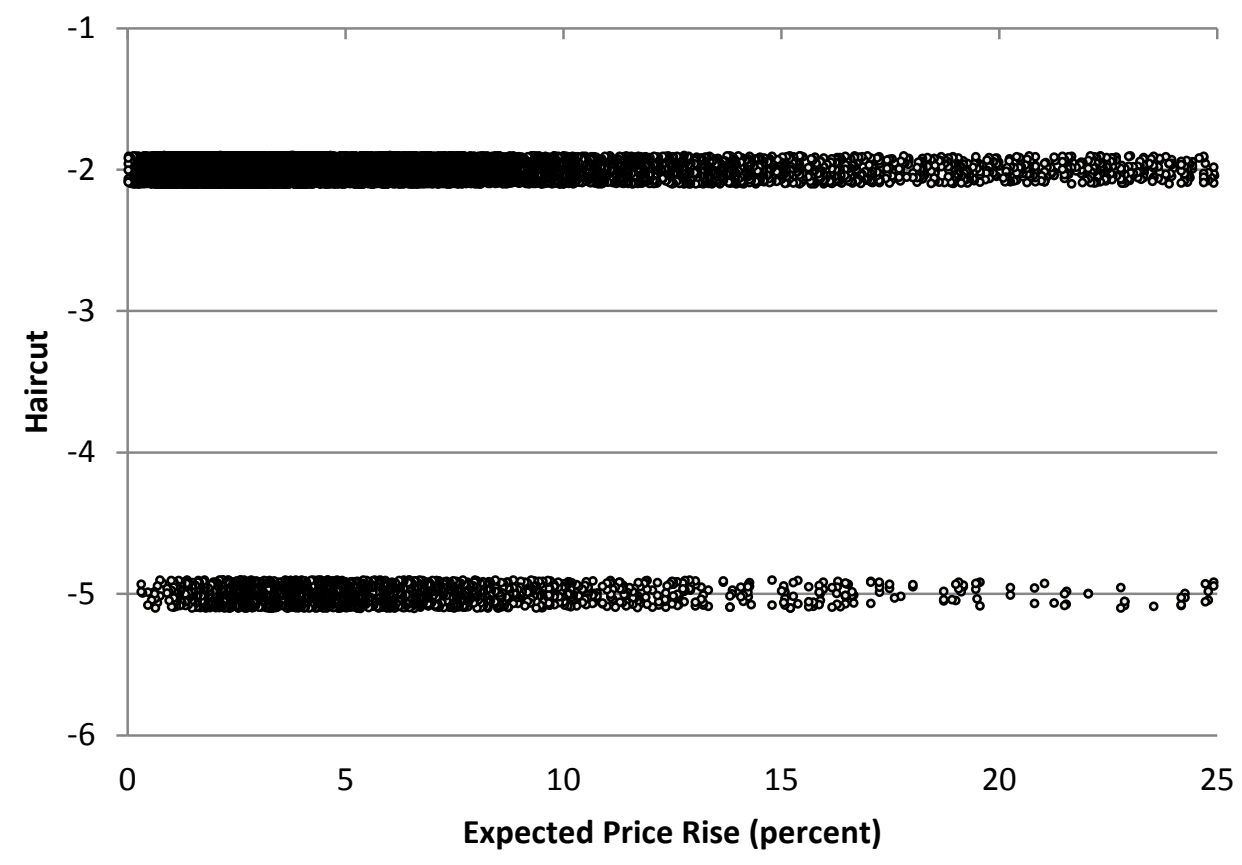

Note: Expected Price Rise is the $90^{\text {th }}$ percentile of the daily percent change in a CUSIP's price conditional on the price change being positive. Security prices are from Bloomberg L.P. over 2014. Excluded observations include inter-company trades, those with small principal amounts, and those with zero haircuts. Small principal amounts for U.S. Treasuries, equities, and corporate debt securities are those less than $\$ 100$, $\$ 10$, and $\$ 100$, respectively. Finally, only overnight or open trades are included. For illustrative purposes, we dropped instances in which the potential price jump was larger than 25 percent, which is roughly 2 percent of the observations. The vast majority of these dropped observations had a haircut of -2 .

Sources: Bilateral Repo Data Collection Pilot, Bloomberg L.P., authors’ calculations. 


\section{APPENDIX}

Table A1: Bilateral Repo Pilot Reporting Fields

\section{Col Field Name}

$$
\text { \# }
$$

\begin{tabular}{|c|c|}
\hline 1 & Transaction ID \\
\hline 2 & Allocation ID \\
\hline 3 & Timestamp of Execution \\
\hline 4 & Legal Agreement Type \\
\hline 5 & “Securities In” or "Securities Out” \\
\hline 6 & Security Dealer Legal Entity \\
\hline 7 & Counterparty Legal Entity \\
\hline 8 & Counterparty Legal Entity Name \\
\hline 9 & Counterparty Top-Tier Parent Company Name \\
\hline 10 & With Related Party or Affiliate? (Yes/No) \\
\hline 11 & Counterparty Legal Entity Type (Sector) \\
\hline 12 & Cleared through FICC? (Yes/No) \\
\hline 13 & Start Date \\
\hline 14 & Rate, or Rate Spread over Benchmark \\
\hline 15 & Benchmark \\
\hline 16 & End Date \\
\hline 17 & Open Maturity Date? (Yes/No) \\
\hline 18 & Optionality Indicator \\
\hline 19 & Notice Period \\
\hline 20 & Allocated ID Type \\
\hline 21 & Allocated Security ID \\
\hline 22 & Allocated Securities Asset Class \\
\hline 23 & Allocated Securities Current Market Value \\
\hline 24 & Haircut \\
\hline 25 & Principal \\
\hline
\end{tabular}

Source: Bilateral Repo Data Collection Pilot 
Table A2: U.S. Bilateral Repo Market Estimates (\$ billions)

\begin{tabular}{l|cc} 
& Securities In & Securities Out \\
\hline 12-Jan-15 & 3,012 & 1,797 \\
10-Feb-15 & 3,071 & 1,822 \\
10-Mar-15 & 3,169 & 1,866 \\
Notes: "Securities In" is a transaction in which the reporting dealer received securities and "Securities Out" is a \\
transaction in which the reporting dealer delivered securities . The method used to produce these estimates is \\
detailed in Copeland et al. (2014a). Bilateral repo estimates are a residual amount, equal to total repo minus tri-party \\
repo. Total repo estimates are based on Federal Reserve FR2004 data collected from primary dealers. These figures \\
include both repo and securities lending activity against cash. Tri-party repo data include General Collateral Finance \\
Repo Service transactions, aka GCF Repo ${ }^{\circledR}$. \\
Sources: For total repo, Federal Reserve Form FR2004; for tri--party repo, Federal Reserve Bank of New York.
\end{tabular}


Table A3: Filtering of Bilateral Transactions

\begin{tabular}{|c|c|c|c|c|}
\hline & \multicolumn{2}{|c|}{ All Securities } & \multicolumn{2}{|c|}{ Securities In } \\
\hline & volume & $\begin{array}{c}\text { value } \\
\text { (\$ millions) }\end{array}$ & volume & $\begin{array}{c}\text { value } \\
\text { (\$ millions) }\end{array}$ \\
\hline \multicolumn{5}{|l|}{ Treasuries } \\
\hline Total & 146,891 & $4,961,891$ & 86,906 & $3,038,264$ \\
\hline Cleaned total & 107,113 & $3,381,767$ & 67,927 & $2,134,617$ \\
\hline without zero haircuts & 36,448 & $1,010,181$ & 26,712 & 712,552 \\
\hline without term trades & 23,245 & 551,373 & 18,018 & 422,521 \\
\hline \multicolumn{5}{|l|}{ Equities } \\
\hline Total & $1,382,429$ & $1,455,033$ & $1,014,570$ & 912,412 \\
\hline Cleaned total & $1,066,857$ & 907,604 & 827,574 & 678,958 \\
\hline without zero haircuts & $1,020,073$ & 741,163 & 786,639 & 584,815 \\
\hline without term trades & $1,006,555$ & 717,374 & 773,196 & 561,990 \\
\hline \multicolumn{5}{|l|}{ Corporates } \\
\hline Total & 266,889 & 417,149 & 188,366 & 295,062 \\
\hline Cleaned total & 143,689 & 212,369 & 114,123 & 177,214 \\
\hline without zero haircuts & 136,323 & 170,095 & 108,890 & 148,481 \\
\hline without term trades & 132,075 & 142,045 & 104,894 & 122,790 \\
\hline
\end{tabular}

Note: All Securities includes all trades, whereas "Securities In" is a transaction in which the reporting dealer received securities. Cleaned total is trades that are not inter-company and are not missing haircut values. Further, for U.S. Treasuries and Corporates, the principal amount of the trade must be greater than $\$ 100$, and for Equities, the principal amount of the trade must be greater than $\$ 10$.

Sources: Bilateral Repo Data Collection Pilot, authors’ calculations. 
Table A4: Regression results of Haircuts on Expected Price Distributions

Haircut

\begin{tabular}{ll|ccc} 
Sign & Asset Class & Price Fall & Price Rise & $\ln ($ principal) \\
\hline \multirow{4}{*}{ Positive } & U.S. & & & \\
& Treasuries & $-23.45^{* * *}$ & - & -0.02 \\
& Equities & - & - & - \\
& Corporate & $-50.06^{* * *}$ & - & $-0.23^{* *}$ \\
\hline \multirow{4}{*}{ Negative } & U.S. & & -4.59 & -0.01 \\
& Treasuries & - & $-0.04^{* *}$ & -0.00 \\
& Equities & - & -0.00 & 0.00
\end{tabular}

Note: Table results are estimated coefficients of a regression of haircut on expected price jump (a rise or fall, depending on the sign of the haircut), the log of the principal amount, ln(principal), with fixed effects for each (dealer, counterparty) pair, CUSIP, and reporting day. The fixed effects are not reported. Zero haircut, affiliated, and small principal trades have been dropped. Small principal amounts for U.S. Treasuries, equities and corporate debt securities are those less than $\$ 100, \$ 10$, and $\$ 100$, respectively. $* *$ and $* * *$ denote statistical significance at the 95 and 99 confidence level, respectively. Standard errors are clustered by dealer and counterparty.

Sources: Bilateral Repo Data Collection Pilot, authors' calculations. 
Figure A1: Distribution of Overnight Interest Rates for Equities Transactions

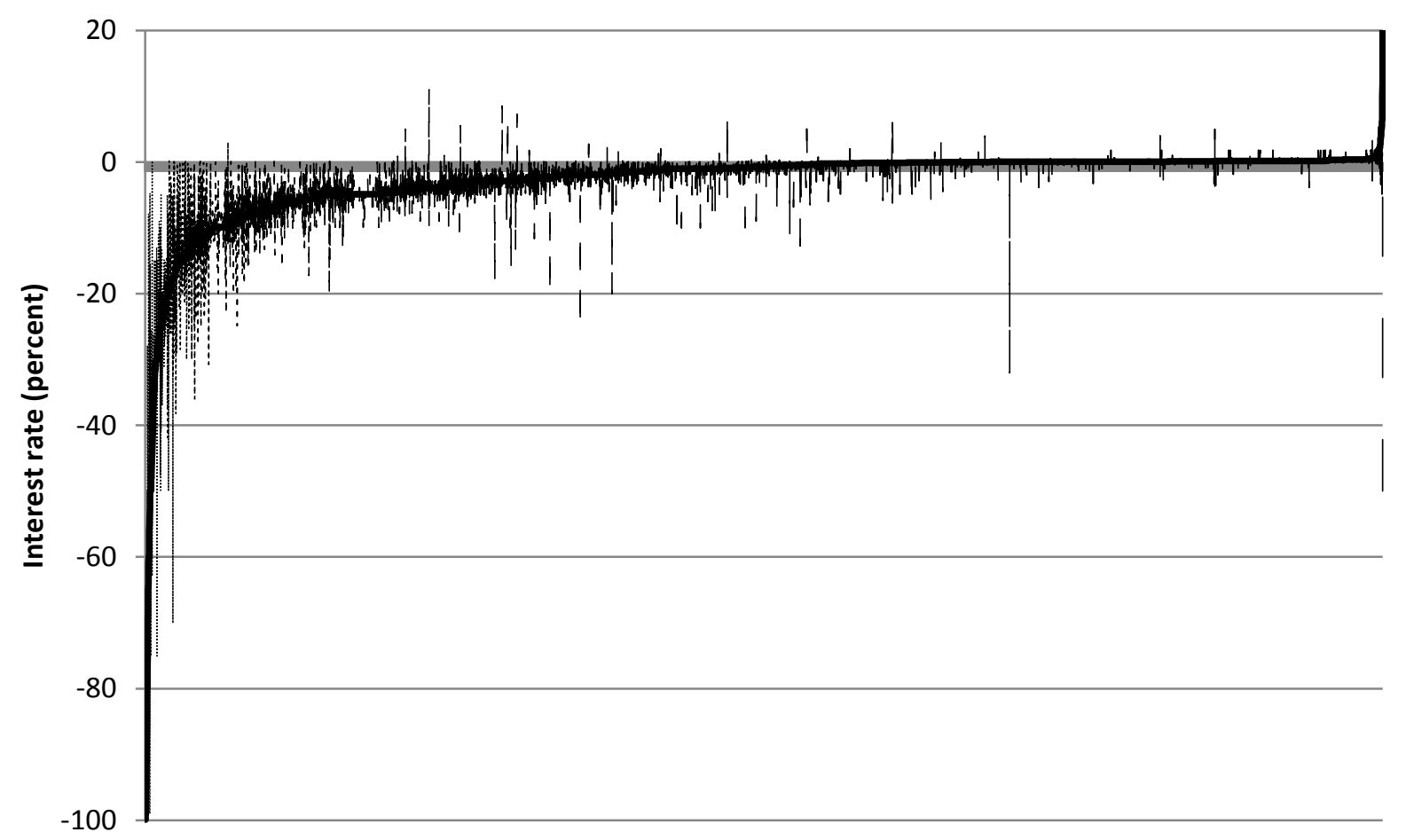

Notes: The solid line is the median rate for a bilateral trade by CUSIP on February 10, 2015. CUSIPs are sorted left to right by the median rate. The dotted lines above and below the solid line are the $25^{\text {th }}$ and $75^{\text {th }}$ percentile of the interest rate distribution for a CUSIP on February 10th.

Sources: Bilateral Repo Data Collection Pilot, authors’ calculations. 
Figure A2: Distribution of Overnight Interest Rates for Corporate Transactions

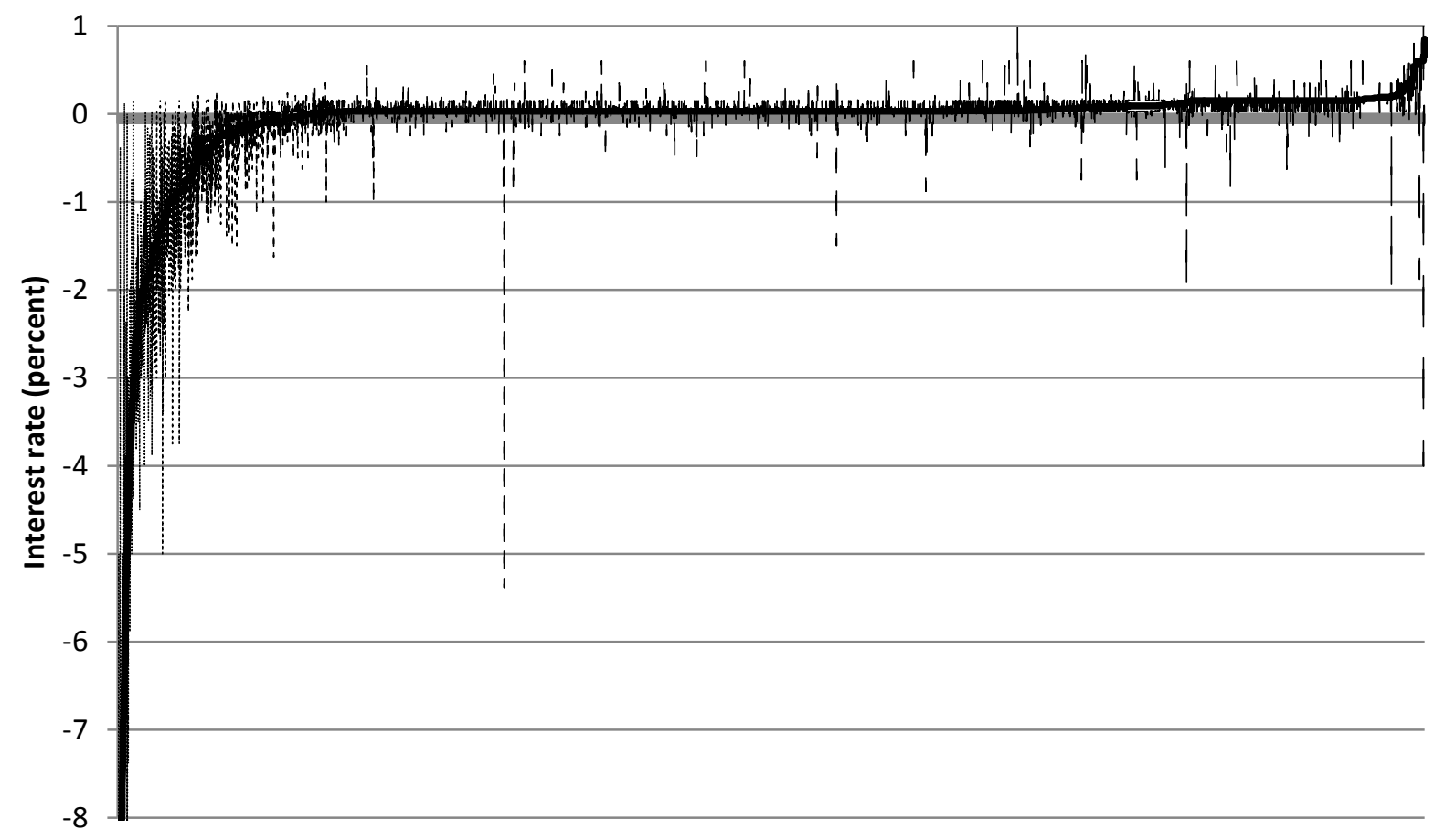

Notes: The solid line is the median rate for a bilateral trade by CUSIP on February 10, 2015. CUSIPs are sorted left to right by the median rate. The dotted lines above and below the solid line are the $25^{\text {th }}$ and $75^{\text {th }}$ percentile of the interest rate distribution for a CUSIP on February 10th.

Sources: Bilateral Repo Data Collection Pilot, authors' calculations. 